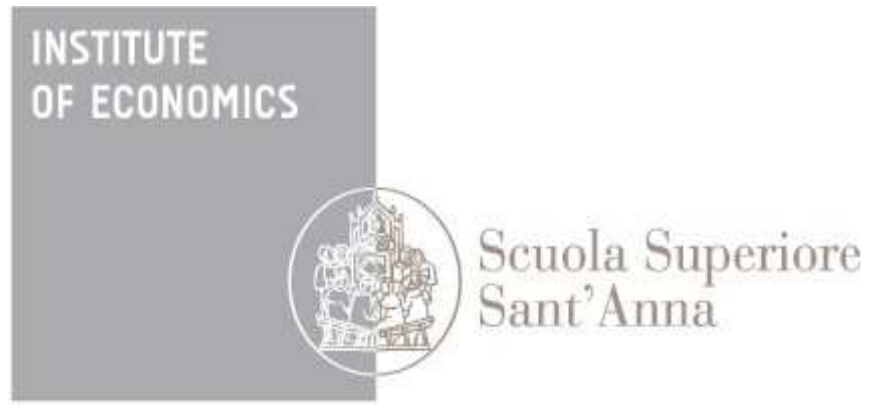

LEM | Laboratory of Economics and Management

Institute of Economics

Scuola Superiore Sant'Anna

Piazza Martiri della Libertà, 33 - 56127 Pisa, Italy ph. +3905088.33 .43$

institute.economics@sssup.it

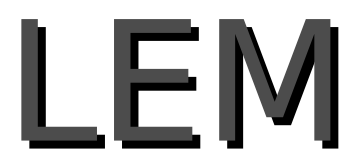

Working Paper Series

\title{
The Innovation-Employment nexus: a critical survey of theory and empirics
}

Flavio Calvino ${ }^{\circ *}$

Maria Enrica Virgillito ${ }^{\circ}$

- Institute of Economics, Scuola Superiore Sant'Anna, Pisa, Italy

* Paris School of Economics, University of Paris 1, France 


\title{
The InNOVATION-EMPlOyment NEXUS: A CRITICAL SURVEY OF THEORY AND EMPIRICS*
}

\author{
Flavio Calvino ${ }^{\dagger a, b}$ and Maria Enrica Virgillito ${ }^{\ddagger a}$ \\ ascuola Superiore Sant'Anna \\ ${ }^{\mathrm{b}}$ Paris School of Economics - University Paris 1
}

\begin{abstract}
Understanding whether technical change is beneficial or detrimental for employment is at the center of the policy debate, especially in phases of economic recession. So far, the effects of innovation - in its manifold declinations and intrinsic complexity - on labour demand have proven to be not unequivocal. This essay critically reviews the role of technical change in shaping employment dynamics at different levels of aggregation. Firstly, it disentangles theoretically the role of different compensation mechanisms through which employment adjusts after an innovation is introduced. Secondly, it critically presents the most recent empirical evidence on the topic, with a focus on methods and limitations. Finally, it provides an attempt to conceptualize a number of stylized facts and empirical regularities on the innovation-employment nexus.
\end{abstract}

JEL classification: D21, J23, L10, O31, O33.

Keywords: Innovation, Technological Unemployment, Compensation Mechanisms.

\footnotetext{
${ }^{*}$ The authors wish to thank Giovanni Dosi, Daniele Moschella, Alessandro Nuvolari, Angelo Secchi, Federico Tamagni and Marco Vivarelli for useful comments and suggestions. The authors only are fully responsible for the views expressed in this paper. Support by the European Unions Horizon 2020 research and innovation programme under grant agreement No. 649186 - ISIGrowth is gratefully acknowledged. The usual disclaimer applies.

${ }^{\dagger}$ Institute of Economics, Scuola Superiore Sant'Anna, Piazza Martiri della Libertà 33, I-56127, Pisa (Italy) and Centre d'Economie de la Sorbonne - Maison des Sciences Economiques, 106-112 boulevard de l'Hôpital, 75647 Paris Cedex 13 (France). E-mail address: f.calvino<at>sssup.it

${ }^{\ddagger}$ Corresponding author: Institute of Economics, Scuola Superiore Sant'Anna, Piazza Martiri della Libertà 33, I-56127, Pisa (Italy). E-mail address: m.virgillito<at>sssup.it
} 


\section{Introduction}

The nexus between technology, innovation and employment is a central area of investigation both from a theoretical and empirical perspective. It has a long tradition in economic research, which starts from the Ricardian conceptualization of technological unemployment, passes by the Keynesian prediction on "mankind solving the economic problem" and culminates in the current debate on the effects of robotization and automation on different occupations. The complex nature of technological progress can be summarized, rephrasing Dosi (1982), as being both an engine and a thermostat. As an engine, it "gives" the rhythm at which a new technological paradigm enters into the market and evolves along its trajectory. As a thermostat, it allows to "control" the diffusion of its waves among different sectors.

Understanding whether technical change is beneficial or detrimental for employment - and consequently whether there exist compensation mechanisms able to counterbalance the two opposing forces - is at the center of the policy debate, especially in the current phase of economic recession. So far, the effects of innovation - in its manifold declinations and intrinsic complexity on labour demand have proven to be not unequivocal. A comprehensive analysis that frames the nexus between technical change and employment, in the light of the most recent contributions, seems therefore necessary.

The aim of this essay is to critically review the role of technical change in shaping employment dynamics. Firstly, this study disentangles theoretically the effects of different compensation mechanisms through which employment adjusts after an innovation is introduced. Secondly, it critically presents the most recent empirical evidence on the topic, with a focus on methods and limitations. Finally, it provides an attempt to conceptualize a number of stylized facts and empirical regularities on the innovation-employment nexus.

Both labour creation and labour displacement seem to be related to different kinds of innovative activities, such as product and process innovation. The distinction between "the introduction of new goods [...]" and the "introduction of a new method of production [...]" is peculiar of the Schumpeterian view. Certainly, as pointed out by Dosi (1984, p. 104), "in practice, product innovation of one sector are often process innovation for other sectors which are using them. The distinction nonetheless is theoretically fruitful". Pianta (2005) underlines how, to some extent, the idea that labour destruction turns out to be a result of process innovation and labour-creation of product innovation, via the openness of new markets hence via consumers demand, is too much simplistic. In fact, as we will better discuss in the following section, the introduction of new products could be addressed to the replacement of existing obsolete ones.

The innovation-employment nexus is determined not only by direct effects, but also by the "types" of compensation mechanism at work (and by the channels through which such mechanisms operate). Furthermore, the level of aggregation at which the relationship between employment and technical change is evaluated is crucial. Peculiarities associated with different levels - namely, firm and sectoral - will be particularly emphasized throughout the analysis.

The skeleton of this survey builds upon the works by Freeman et al. (1982), Vivarelli (1995), Spiezia and Vivarelli (2002), Pianta (2005) and Vivarelli (2014). It however departs from previous analyses in different respects: [i] it discusses most recent firm-level and industry-level contributions, focusing on the last decade since 2000, with particular attention to differences in methodologies and limitations; [ii] it emphasizes the impact of the aggregation level on the innovation-employment nexus; [iii] it investigates in detail the extent to which compensation 
mechanisms operate at firm and industry level; [iv] it discusses the firm-industry linkage integrating results from shift and share decompositions of productivity on employment shares; [v] it focuses on the effect of business cycles, and on how they mediate the innovation-employment relationship.

This study is organized as follows. The research questions and the theoretical background are presented in Section 2, in Section 3.1 we discuss the most recent empirical findings at the firm level, in Section 3.2 we focus on shift and share decompositions of productivity with employment shares, while in Section 3.3 we discuss industry-level analyses. Section 4 proposes a number of stylized facts and Section 5 concludes, emphasizing what is left out of the scope of this work and pointing to promising avenues for further research.

\section{The general theoretical framework}

The relationship between innovation and employment dynamics is a key issue in economic theory. However, disentangling this nexus reveals to be particularly complex, both from a theoretical and an empirical perspective.

Our starting point is an enquiry on the alternative theoretical approaches, which can be classified in equilibrium perspectives (Neoclassical analyses) and disequilibrium perspectives (namely, Evolutionary, Keynesian, Structural and Regulationist theories). The main disagreement between the two views concerns the possibility of a self-adjustment process that starts as soon as innovation is introduced. According to the former, higher innovation induces increases in productivity hence in the growth rate. The causal effect goes from more innovation to higher employment, via increase in total output and wages reduction. According to the latter, the effect of innovation on employment is not unequivocal, framing technological progress as a complex phenomenon.

Starting from different theories about the technology-employment nexus, this section goes through the analysis of the alternative compensation mechanisms proposed by distinct schools of thought, together with their limitations.

\subsection{Competing theories on the innovation-employment nexus}

How has the relation between innovation and employment evolved along the course of the economic thought? During the pre-Classical era, the Mercantilists took into serious consideration the potentially detrimental effect on employment associated with the introduction of new machineries. Particularly, as recorded by Freeman and Soete (1994), a number of regulations were introduced in France and in England directly aimed at controlling the use of machineries in the production process (i.e., limiting the use of calico or sewing machines). In the debate of that period, according to James Steuart, governments should have endorsed active protectionism of strategic industries in order to avoid mass unemployment and social revolts.

The active interventionism of the Mercantilist approach was discarded since the diffusion of the so-called laissez-faire principle: thanks to the mechanization of labour, a subsequent reduction in prices would have induced a welfare enhancement in the long run, compensating for the initial labour displacement. Despite the pervasiveness of this argument among both economists and policy makers, David Ricardo was the most prominent Classical economist who critically questioned the long run benefit of technological innovation, stressing the labour-saving 
bias induced by new technologies:

That the opinion entertained by the labouring class, that the employment of machinery is frequently detrimental to their interests, is not founded on prejudice and error, but is conformable to the correct principles of political economy. Ricardo, 1817 .

The quotation above suggests that a substantial debate was already in place during the Classical period, and that a unifying theory on the relation between employment and innovation was strikingly lacking. The possibility of temporal mismatches and the emergence of rigidities in the adjustment process - originating from the supply side (labour force) - emerged already in that period. Following Ricardo, also in the Marxian perspective, technological advance is "rationally" led by capitalists in order to increase unemployment, as mean of control on the labour force, but with the predominance of the Neoclassical view, the idea of a self-equilibrating mechanism - based on the cornerstone of the Say's Law - pervaded the discipline.

Along with the general equilibrium view, the principle of factors substitution became one of the main pillars of economic analysis. According to this principle, the most profitable combination of labour and capital given current prices can be effectively pursued. Under market-clearing mechanisms, overproduction and unemployment are theoretically ruled out. Technological innovation can simply lead to temporal labour destruction and the possible mismatch is not due to the lack of job opportunities - squeezed by technical progress - but by the lack of an adequate lower equilibrating salary, able to match the reduced demand of labour. Analysing the series of succeeding effects, the relative capital depreciation induced by technological progress results into a lower interest rate, fuelling the investment activity. Two opposite forces interact in the market for capital: on the one hand, under decreasing returns to scale, the marginal efficiency of capital decreases along with capital accumulation, reducing the related demand. On the other hand, the supply of capital tends to decrease, triggered by the low interest rate. The interest rate clears the market for capital. On the labour market, wages play the equivalent equilibrating role of interest rates for the capital market.

A rather opposite perspective with respect to the self-regulating equilibrium argument characterised the Keynesian approach, which circumscribed the validity of the Say's law only to full-employment conditions. The popularised version of the Keynesian perspective suggests that in situations of under-employment, without any external intervention in the market, there is no room to get out from stagnation-depression periods.

The major distinction between Keynes and Neoclassical economists, can be primarily stated in terms of their inner theoretical view of the economic system, rather than in terms of the extent to which a State should intervene:

On the one side were those who believed that the existing economic system is in the long run self-adjusting, though with creaks and groans and jerks, and interrupted by time-lags, outside interference and mistakes. [...] Those on the other side of the gulf, however, rejected the idea that the existing economic system is, in any significant sense, self-adjusting. They believed that the failure of effective demand to reach the full potentialities of supply, in spite of human psychological demand being immensely far from satisfied for the vast majority of individuals, is due to 
much more fundamental causes. [BBC Radio address, 1934, reprinted as Keynes, 1963 .

In the General Theory unemployment is all but a temporary phenomenon and cannot be "solved" within the labour market. During the recession phase, the low level of aggregate demand will turn out into lack of private investments, due to negative expectations on future profits. To boost the economy towards a recovery phase, aggregate demand has to be stimulated, reestablishing a period of positive investment expectations. Higher investment will translate into higher demand for labour hence reducing unemployment. However, in the Keynesian framework, limited attention is devoted to the role of technical progress and to the introduction of laboursaving technologies 11 As a matter of fact, Keynes develops a theory of booms and bursts lead by the process of investment activity. But such process of investment, in the General Theory, is only connected to an undefined idea of profits expectations.2 The determinants of investment expectations are however not discussed in depth and "black-boxed" into the concept of "animal spirits". In this context, it is noteworthy to emphasize that the Keynesian view does not portray innovation as the engine of investment activity.

On the contrary, the Schumpeterian analysis has been notably direct to disentangle the role of innovation in shaping economic dynamics. Particularly, it is built on the ideas of clustered innovation, product life cycle, imitation and diffusion: the interplay of these elements determines the emergence of cycles or waves where periods of growth, due to the launch and diffusion of new products, alternate with periods of market saturation. Unemployment arises as a result of technological innovation, whose diffusion takes considerable time and asymmetrically affects different sectors. Innovation is conceptualized as a painful process, which creatively destroys the old and opens the way for the new. But Schumpeter does not believe in the possibility of structural/Keynesian unemployment (see Dosi et al., 1988).

The Schumpeterian legacy was inherited by neo-Schumpeterian/new growth theories, with a continuing emphasis on the supply side, and by evolutionary-institutionalist theories. The latter - mainly endorsed by Chris Freeman, Carlota Perez and Luc Soete - tries to better refine the Schumpeterian idea of economic fluctuations linking a notion of long swings - sometimes associated with Kondratieff long waves (Kondratieff and Stolper, 1935) - with the emergence of technoeconomic paradigms $3^{3}$ In this view, the establishment of a new technological paradigm (Dosi, 1982) occurs by means both of technological factors and institutional components. According to Freeman and Perez (1988), in presence of misalignments between the tecnoeconomic conditions and the social environment depressions arise. Broadly speaking, it is a matter of "waiting" the re-conjunction of the two sides. From a less deterministic perspective, instead, the Regulationist school - mainly Boyer (1988) - categorized alternative archetypes of capitalism nested in the coupling between the accumulation regimes and the modes of regulation.

\subsection{On the "Compensation mechanisms": is there any self-adjustment pro- cess?}

As suggested in the previous section, different schools of thought conceptualize (or not) alternative channels that balance the effects of technical change on employment. Freeman et al. (1982),

\footnotetext{
${ }^{1}$ Notwithstanding Keynes popularized the concept of technological unemployment (see Keynes, 1931).

${ }^{2}$ See chapter 12 of the General Theory.

${ }^{3}$ Technoeconomic paradigms are intended as macro constellation of technological paradigms introduced in Dosi (1982).
} 
Vivarelli (1995), and more recently Vivarelli (2014) have proposed a classification of the different compensation mechanisms in terms of the alternative "pass-trough" channels that trigger the transmission chain of the economic effects. Following this stream of literature, we distinguish between Classical-Neoclassical and Keynesian-Schumpeterian mechanisms.

Classical-Neoclassical mechanisms can be classified as follows:

- New machines. As the result of technical progress, new machines are introduced, possibly displacing labour. A "sectoral shift" of workers from the machine-using industry towards the machine-producing one counterbalances the initial detrimental effect on employment.

- Decrease in prices. The increase in productivity due to the introduction of new technologies induces a reduction in production costs. This effect in competitive markets induces a consequent reduction in prices. Lower prices should translate into higher demand, and therefore higher employment.

- Decrease in wages. This mechanism acts in the market of production factors and exerts effects symmetric to the process of price reduction. Workforce displacement leads to an excess of labour supply, hence to a reduction in wages. An increase in labour demand re-equilibrates the market tension responding to the first wave of excess labour supply.

- New investments. The accumulated extra-profits in the temporal gap between the decrease in the unit costs and the subsequent decrease in prices can be invested by entrepreneurs in physical capital, expanding the productive capacity hence the labour demand.

Keynesian-Schumpeterian mechanisms can, instead, be categorized as follows:

- Increase in incomes. Whenever workers are able to appropriate the gains from increase in productivity, technical progress can lead to an increase in wages and consumption. This turns out in higher demand that induces an increase in employment via the well-known Keynesian mechanism, compensating for the initial labour displacement.

- New products. The introduction of new branches and products can stimulate consumption. Higher consumption translates into higher demand and hence higher employment. Under the traditional Schumpeterian distinction between product and process innovation, the former is recognized to be labour-friendly while the latter as labour-displacing. However, in order to exert a compensating effect, new products should not be addressed exclusively at replacing the obsolete ones. In this respect, at the firm level, new products can cannibalize sales of old products, resulting in ambiguous net effects. Furthermore, at industry level, product innovators on one hand can face a demand increase (via market expansion) as the new product might satisfy previously unmet consumers' needs. This effect is positive on employment. On the other hand, product innovators can erode market shares of non-innovators (via the so-called business stealing effect), as old products become obsolete 4 Finally,

\footnotetext{
${ }^{4}$ See also Harrison et al. (2014).
} 
one should not forget that new products can be produced more efficiently, due to the complementarities existing between product and process innovation strategies.

Unfortunately, the effectiveness of the above mentioned compensation mechanisms is all but deterministic: many aspects intertwine undermining the possibility of any ex-ante exhaustive prediction about their relative efficacy. Let us focus on a number of possible limitations.

Starting from the introduction of new machines, there is no ex-ante reason that prevents mechanization from moving across sectors: the structural change from agriculture to manufacturing, and from the latter to services, is a clear-cut example of the overall spreading of technical change across sectors. Even though the direction of the rate of absorption of the workforce moved from the first two sectors toward the tertiary, nowadays part of the service sectors is experiencing a strong reduction in labour demand. Additionally, the higher the rate of technical change, the higher the obsolescence of machineries, inducing scrapping and substitution. If the introduction of new machines is directed at replacing the obsolete ones, no compensation would arise 5

The compensation mechanism via decrease in prices, in order to work properly, needs to counterbalance the reduction in aggregate demand associated with workers dismissal. Necessary conditions for its effectiveness include: [i] significant price elasticity for the commodities that are affected by the price reduction; [ii] high relevance of these commodities in workers' consumption bundles; [iii] non-oligopolistic market structures. The extent to which the composition of aggregate demand is affected by price reductions depends therefore crucially on whether the above conditions are fulfilled. Limited validity of such conditions can result in unchanged - or even reduced - aggregate demand.

A similar framework would also apply to the wage reduction channel. However, this mechanism is additionally based on the principle of factor substitution. A number of theoretical flaws can undermine its effectiveness. They include: [i] the fact that technology is not time-reversible: if a firm masters a given technique, it will hardly stop to use it and substitute it with labour because of a change in relative prices (see Dosi and Nelson, 2010); [ii] in presence of a theoretical isoquant that represents the negative relationship between capital and labour, a similarly negative relationship between capital and labour productivity would be also expected. However, contrary to what theoretically predicted, Hildenbrand (1981), Dosi et al. (2016) and Yu et al. (2015) empirically trace a zero or positive correlation between the two, providing evidence in favour of the absence of factor substitutability; [iii] the possibility of re-switching of the techniques due to multiple intersections of the isoquants (for a recent discussion on the Cambridge capital theory controversies, see Cohen and Harcourt, 2003) would allow, given the same relative prices, to have a coexistence of multiple capital/labour combinations. Even assuming that the production factors have a certain degree of substitutability ${ }^{6}$ it would be not easy to imagine that the direction of such substitutability goes from capital intensity to labour intensity (in a given geographical area). The inherent concept of progress is, in fact, strongly related with the unilateral direction of technical change.

\footnotetext{
${ }^{5}$ Note that the same mechanism is in place in the case of the introduction of new products confirming the absence of a clear-cut border between process and product innovation. As a matter of fact, looking at new machines in the machine-producing industry as a product, if complete cannibalization arise such industry would not benefit from any positive effect on employment.

${ }^{6}$ In this respect, Bessen (2015) argues how, in the estimation of an engineering production function of the U.S. cotton industry in the 19th century, a very low elasticity of substitution between looms and weavers emerges.
} 
The previously described limitation also affects the compensation mechanism via new investments. Even under the effectiveness of the Say's law - case in which all the accumulated profits are reinvested - they will be directed to labour-saving machineries, breaking down the Keynesian channel that links more investment with more production, and more labour demand.

Furthermore, the new investment channel would properly work if limited to real investments. However, nowadays the rate of investment in the real economy appears lower than the rate of investment in purely financial activities. In particular, Lazonick (2011) describes the process of financialization occurring at the the firm level where during the last twenty years, the "retain-reinvest" strategy have been translating into a "maximizing shareholder value" strategy. The change of paradigm in investment activities is fairly evident when the massive increase of buybacks operations is taken into consideration.

The income channel revealed to be mostly effective under a Fordist mode of production, where unionised labour was able to exert significant pressure on capitalists. Currently, a more fragmented labour force appears intrinsically less able to lay collective claims, partly as a consequence of a different mode of industrial relations increasingly based on certain degrees of flexibility and individual bargaining.

Finally, the new products channel looks rather subtle. Analysing its history and diffusion, ICT has been among the sectors with the highest rate of employment absorption in the last three decades (see Freeman et al., 1982 and Freeman and Soete, 1994), responsible for the most significant products innovation (such as personal computers, mobile phones and so forth). However, ICT represents a process innovation for many related ICT-using industries.

One of the first attempts to empirically test the validity and effectiveness of all the compensation mechanisms is proposed by Vivarelli (1995). The author builds a theoretical macroeconomic model which combines both technological and market drivers. Focusing on the period between 1960 and 1988 in Italy and U.S. by means of a three-stage least squares regression, Vivarelli (1995) shows that the most effective compensation mechanism in both countries is the one "via decrease in prices", while other mechanisms reveal to be less important. Nonetheless, this mechanism seems to partially compensate only the total contraction in labour demand. Moreover, in both countries the wage compensation mechanism does not effectively counterbalance unemployment. The U.S. economy in the period under analysis turns out to be more productoriented (and so characterized by a positive relationship between technology and employment) than the Italian economy, in which different compensation mechanisms could not counterbalance the labour-saving effect of prevailing process innovations.

In a subsequent work, Simonetti et al. (2000) compare American, Italian, French and Japanese data between 1965-1993, confirming substantially analogous results. In their analysis, the authors emphasize that price and income seem the most effective compensation mechanisms in the economies under scrutiny, irrespectively from country-specific institutional factors. Again, product innovation appears to be particularly effective in the United States.

Concluding, the complexity that involves the innovation-employment nexus is remarkably high. A comprehensive - all but simplistic - perspective seems therefore necessary to disentangle its nature. Non-Neoclassical approaches have historically proven to be more prone to recognize the articulated form of technology, as a set of knowledge made by repeated acts, procedures, routines. If this is the case, technology is tacit, rarely transferable and not easily substitutable. Removing the pillar of factors substitutability and taking into account the local, cumulative and 
non-reversible nature of technology, the extent to which a significant portion of compensation mechanisms apply seems to be more limited.

A general disequilibrium perspective (or a general equilibrium one) seems suitable to properly frame the effects of compensation mechanisms at different levels of aggregation: the success of one firm cold be the failure of its competitors; the emergence of one sector could mark the end of another one.

\subsection{Income and price elasticities as determinants of sectoral composition}

What is the role of sectoral specificities and how innovation and employment intertwine when sectoral specificities are considered? Is there any sector-specific technology-employment nexus? Along the process of economic development, which are the labour shedding and the labour absorbing sectors? And how economic development affects the transition phase from sector to sector? Historically, the pattern of economic growth induced a movement of the labour force from agriculture to manufacturing, and finally to the third sector (see for instance Landesmann and Pichelmann, 1999). This transition occurred according to an S-shaped curve, leading to a process of employment reallocation across sectors. In this view, the rate of technological progress unevenly spreads both in time and in space: on the one hand, periods of strong innovations are followed by periods of mild diffusions; on the other hand, highly productive sectors coexist with very unproductive ones.

The prevalence of the labour-creative or destructive effect accompanying the process of structural change mainly depends on whether output growth (demand) is higher/lower than productivity growth (which proxies the pace of technical change). Demand growth and productivity growth are linked by the price elasticity channel: productivity differentials, reducing consumer prices, lead to a stimulus of demand in sectors experiencing high productivity growth (see also Kuznets, 1955, Clark, 1957, Baumol, 1967, Pasinetti, 1983). On the other hand, the structure of the Engel curve - i.e., the income elasticities of demand - plays a role in influencing the dynamics of inputs and relative productivity. For these reasons, the employment absorbing sectors (toward which the labour force moved) have been generally characterised by high labour intensity and high income elasticity of demand, in the initial phase of development (Freeman et al., 1982). The first factor implies that demand growth ensures a sufficient creation of new jobs. The second factor implies that in the phase of development demand shifts toward these sectors.

Two opposite theories on the relation between productivity and growth are proposed by Salter and Kaldor. Both authors share the idea that productivity differentials and output growth performances are correlated, but they suggest an opposite "causality direction". For the former the causal chain goes from productivity to growth, for the latter the opposite applies (the so called Verdoon-Kaldor's law). In this perspective, the effects of technological progress on employment are transferred by means of two possible elasticities: [i] the price elasticity of demand and [ii] the productivity elasticity of prices (how productivity changes affect price). The net effect resulting from the interplay between these two elasticities traces the phases of technological waves. As emphasized by Freeman et al., 1982, the different stages of the productivity-demand cycle can be summarized as follows.

The starting phase of business activity is usually characterized by an intense innovative effort and by a monopoly pricing, with productivity gains mainly appropriated by capital owners. In 
the subsequent phase - but still in the early stage of development - when other firms enter, the industry structure moves toward oligopolistic competition inducing a price reduction. The evolution of the industry depends on the appropriability conditions of the market, particularly in the ability of incumbents to gain dominant positions in terms of market shares, on the cumulativeness of innovative opportunities (Schumpeter Mark II), and on the entry barriers and the easiness of imitation (Schumpeter Mark I). The arrival of newcomers tends to erode the oligopolistic power of incumbents. This might have two effects: [i] a fall in prices would shift the distribution of productivity gains from capital owners to consumers, [ii] productivity gains can be distributed among workers (mitigating conflict claims). The mature phase generally records higher output growth due to a decrease in prices and demand stimuli (Salter's view) and higher wages; in a phase of rapid income growth, the development of new products and consumer needs trigger demand 7 growth, employment and productivity (Kaldor-Verdoon's law).

From a historical perspective, in periods of increasing wage remuneration as the post World War II, the demand-price elasticity became weaker and a stronger income elasticity prevailed. Broken down the demand sensitivity on prices, also the productivity-demand-growth-employment relationship was replaced by a wages-demand (new products)-growth-employment nexus. This seems to suggest that in the initial phase of industry development, process innovation triggers the advance in technological progress. Via the productivity-price elasticity, gains are transferred to consumers. In mature phases, and particularly in growing income periods, technological advances appear conversely triggered by the introduction of new products: in this respect, output growth and the related possibility of employment growth are primarily related to the satisfaction of consumer needs.

The interpretation proposed by Utterback and Abernathy (1975) and Abernathy and Utterback (1978) leads to an opposite view on the prevailing dominance between product and process innovation in the phase of development of an industry. Distinguishing between radical and incremental innovation, they emphasize how in the first stage of development the introduction of new radical products boosts the industry activity. Conversely, in the later stage, processes of standardization, refinements and cost reduction take over the frequency of radical innovation. They report the case of semiconductors, DC-3 and the electric light bulbs as examples of radical innovations later succeeded by a series of productivity improvements.

Let us now move form theory to empirical analyses disentangling the extent to which compensation mechanisms work, at firm and sectoral level.

\section{From firms to sectors: the role of aggregation}

This section critically reviews a considerable number of empirical contributions that analyse the links between innovative activity and employment at firm level (Section 3.1) and sectoral level (Section 3.3). An evolutionary trait d'union between the micro and the industry level is proposed in Section 3.2 .

This section complements and significantly extends the scope of other reviews (such as $\mathrm{Pi}-$ anta, 2005 and Vivarelli, 2014, which mostly focus on evidence during 1990s and early 2000s). Empirical evidence on how the relationship between innovation and employment changes over

\footnotetext{
${ }^{7}$ At our knowledge, little research has been oriented at investigating the pattern of time evolution of demand. The Engel law remains one of the few robust empirical regularities, according to which higher income correspond to a decline of food expenses.
} 
the business cycle is also presented. Particular attention is devoted, differently from previous surveys, to a critical analysis of the different methodological approaches used and of their limitations. Substantial space is given to contributions that account for the effects of innovation over the entire employment growth distribution.

A particular effort, throughout this essay, is made in the attempt to reconcile results at different levels of investigation (firm-level vs. industry-level), especially when specific kind of innovations are analysed separately or when the empirical work goes beyond the analysis of conditional average effects. Synopsis sheets are available in the Appendix, allowing a schematic visualization of the studies presented and including further details (see Tables 3,4 and 5 ).

\subsection{Firm-level empirical evidence}

The empirical debate on the innovation-employment nexus at firm level is long standing. As emphasized by Vivarelli (2014), the micro-econometric literature tends to support the existence of a positive relation between innovation and employment, especially when R\&D or product innovation are adopted as proxies of innovative activity and mostly when high-technology sectors are the center of the analyses.

A number of micro-econometric studies use R\&D intensity or patent counts as proxies of innovative activity. Such studies are not able to disentangle the effect of any of the compensation mechanisms presented above, but generally estimate correlations which are the net outcome (on employment) of the complex interaction of different forces. Other studies exploit the granularity of firm-level surveys (such as the Community Innovation Survey in Europe) to separate the effects of innovation on employment into the components originating from product and process innovation, with different econometric techniques. Despite the limitations associated with such databases, this decomposition is able to catch peculiar aspects on employment related to product innovation (and to the compensation mechanism via new products) 8 Finally, other contributions pursue a structural modeling approach and aim at disentangling the extent to which other compensation mechanisms (such as the one via decrease in prices) affect the (otherwise net) effect of process innovation on employment.

A word of caution is necessary when interpreting findings of the firm-level analyses presented. The scope of this stream of literature does not always directly nor automatically allow to infer industry-level dynamics. It is therefore not obvious to interpret a positive effect of innovation on employment at firm level as evidence of the fact that innovation induces a general increase in employment at industry (or society) level. As a matter of fact, business stealing and market expansion, competitive and selection dynamics, firm entry and exit, relocation of activities, may induce completely different patterns at higher levels of aggregation. In addition, generally no conclusion is drawn on the effects on the composition of employment nor on the persistence of jobs created. Further discussion in the following will clarify limitations associated with the different micro-econometric studies.

\footnotetext{
${ }^{8}$ Such surveys also allow to catch the effects of organizational innovation. We do not particularly focus on effects related to this specific innovative activity in our work. See for instance Evangelista and Vezzani (2012) or Peters et al. (2014) for further discussion.
} 


\subsubsection{R\&D, patents and employment}

Traditional analyses of the firm-level impact of innovation on employment use R\&D expenditures or patent data as proxies of innovative activity. Acknowledging the limitations of the two measures used in isolation, a few contributions also take advantage of composite innovation indicators, including a combination of patents and $R \& D$ intensity. Many studies in the literature have suggested the existence of a positive relationship between innovation measures and employment or employment growth (see among the others Hall, 1987, Yasuda, 2005 and Yang and Huang, 2005 for R\&D; Van Reenen, 1997 and Greenhalgh et al., 2001 for other composite measures). Other works find a less clearcut evidence (see for instance Brouwer et al., 1993, Klette and Førre, 1998 for R\&D and Piva and Vivarelli, 2005 for other measures). In the following, we will concentrate our attention on the most recent empirical evidence.

Studies that focus on different samples, which have peculiar characteristics in terms of age and size of the firms under scrutiny are able to offer different perspectives on the microeconomic relationship between innovation and employment. In this respect, we will start focusing on young firms, shifting then the attention to small, and subsequently larger ones. Regardless of firms characteristics, however, technology reveals to be an important factor that mediates the extent to which innovation influences employment dynamics. In particular, we will emphasize peculiarities associated with high-technology sectors.

In particular, using R\&D behavior as a proxy of innovation, Stam and Wennberg (2009) focus on its impact on new product development, inter-firm alliances and - relevantly for our purpose - employment growth of newly born firms. Stam and Wennberg (2009) exploit a comprehensive start-up database covering biannually the Dutch economy, from 1994 to 2000. Their findings suggest that there is no significant relationship between R\&D activities and employment growth, unless the attention is restricted to the $10 \%$ fastest-growing firms. They further suggest that R\&D is positively associated with the growth of young high-technology firms, but not with low-tech start-ups' employment growth.

Further investigating the role of the fastest-growing firms, but focusing on high-growth SMEs and not only on start-ups, Hölzl (2009) studies how innovation and knowledge intensity affect employment growth and its distribution. The author exploits CIS 3 data from 16 economies and groups them according to their distance from the technological frontier. Hölzl (2009) suggests that innovation success and R\&D intensity are crucially important for high-growth SMEs in countries closer to the technological frontier 9 Moreover, high-growth SMEs look more innovative than non-high-growth SMEs exclusively in economies which are closer to the technological frontier. This confirms not only considerable heterogeneity of the effects of innovation at firmlevel, but also substantial cross-country differences in the innovativeness of high-growth SMEs, depending on technology.

Shifting the attention to large firms, Bogliacino et al. (2012) assess how in-house corporate R\&D affects employment on a panel of about 700 European large publicly traded companies, between 1990 and 2008. They estimate a dynamic labour demand equation augmented with innovation variables by means of a Least Squares Dummy Variable Corrected (LSDVC) estimator ${ }^{10}$ Separately focusing on manufacturing (high-tech vs. low-tech) and services, their results highlight - once again - that the positive impact of R\&D expenditures on employment is not

\footnotetext{
${ }^{9}$ Despite a decrease in magnitude of such effects in the very top $5 \%$.

${ }^{10}$ More sophisticated than GMM in a dynamic panel setting with better performances when the sample is relatively small and unbalanced (see Bruno, 2005 for further details).
} 
significant in low-tech manufacturing sectors but it is detectable in services and in high-tech manufacturing.

Restricting the focus to the high-tech manufacturing sector, where the positive role of innovative activities proved so far more intense, Coad and Rao (2011) combine patent and R\&D data to investigate the relationship between innovation and employment growth in the United States ${ }^{11}$ They build a synthetic innovation indicator matching Compustat data with the NBER Innovation database, this way limiting the possible drawbacks associated with the use of just one innovation measure individually (see Dosi, 1988). Combining OLS with WLS and LSDVC methods, Coad and Rao (2011) argue that - in general - innovation is positively associated with subsequent employment growth in the U.S. high-tech manufacturing industry. Moreover, they present evidence in favour of a substantial variation in the regression coefficients over the conditional quantiles of the employment growth distribution, confirming that innovation is significantly associated with employment growth for fast-growing high-tech firms while it has almost no effect on high-tech firms experiencing rapidly negative employment growth.

Finally, Van Roy et al. (2015) further exploit patent data in a cross-country panel database of European patenting firms, covering the period 2003-2012 12 Differently from many contributions, this study includes patent quality information (based on forward citations) into the exploration of the innovation-employment nexus. Van Roy et al. (2015) estimate a labour demand equation augmented with (lagged) innovation by means of a system GMM approach. Their findings highlight a significantly positive effect of (citation-based) patenting activities on employment (doubling patenting increases employment by 5\%). Furthermore, such positive effect remains significant only in high-tech manufacturing sectors, confirming the important role of technological characteristics in this framework.

The first block of studies above presented tends to confirm a generally positive role of innovation on employment growth, at the firm level. This seems to hold particularly true for high-growth firms in high-tech sectors located in most innovative countries. However, the scope of these studies does not allow a separate investigation of the effects of product and process innovation nor to test whether any of the above-described compensation mechanisms mediate the link between innovation and employment.

\subsubsection{More on product and process innovation}

Over the last two decades, a number of empirical contributions have tried to disentangle the effect of product and process innovations on firm-level employment. Most studies have found a positive link between product innovation and employment in businesses, especially when the products are not only new to the firm but also new to the entire market, while process innovation effects look more ambiguous (see among the others Pohlmeier and Entorf, 1990, Brouwer et al., 1993, Smolny, 1998 and Greenan and Guellec, 2000). Identifying the relationship between different types of innovation and employment is not an easy task and, as previously discussed, empirical estimates might reflect a combination of direct and indirect effects associated with innovative activity.

\footnotetext{
${ }^{11}$ They focus on four 2-digit SIC codes sectors: industrial and commercial machinery and computer equipment; electronic and other electrical equipment and components, except computer equipment; transportation equipment; measuring, analyzing and controlling instruments; photographic, medical and optical goods; watches and clocks.

${ }^{12}$ The authors highlight that one needs to take into account that most patented innovation are products, as process innovation can be embodied into machines and kept secret more easily.
} 
Within this stream of literature, a key contribution to the empirical and methodological debate is by Harrison et al. (2014) 13 The authors develop a framework in which they establish a firm-level theoretical relationship (within a production function setting) among employment growth, the dynamics of innovation output (product innovation), and productivity gains associated with process innovation. They then exploit data from the third wave of the Community Innovation Survey (CIS) between 1998 and 2000 for Spain, Germany, the U.K. and France to empirically test the model. Harrison et al. (2014) argue that an overall positive relationship between innovation and employment holds at the firm level. Productivity improvements and process innovations tend to reduce employment, if output is held fixed 4 However, output expansions of older products seem to overcome this effect, increasing employment. Reduction of prices, associated with process innovation, appears to boost output expansion (suggesting indirect evidence in favour of the existence of an effective price compensation mechanism), despite its magnitude can be time-specific. Furthermore, Harrison et al. (2014) confirm that major source of firm-level positive employment changes is product innovation.

By developing a theoretical framework that allows to disentangle the effects associated with different types of innovation - accounting for a number of compensation mechanisms and estimating counterfactual industry-level effects, as will be discussed in the following section -, the model by Harrison et al. (2014), together with its previous versions (see for instance Harrison et al. 2008), has been further exploited in a number of recent empirical exercises focused on different countries. In particular, Hall et al. (2009), by using data from the Mediocredito-Capitalia innovation survey from 1995 to 2003, do not find any evidence of displacement effects induced by process innovation in Italy. They suggest that during the period examined employment growth sources equally come from product innovation and from old products' sales growth. They also highlight that the contribution of product innovation looks however lower if compared to the countries analyzed by Harrison et al. (2008) and that innovative activity does not contribute to productivity growth in Italy during the sample period 15 Benavente and Lauterbach (2008) analyze, instead, micro-data from Chile between 1998 and 2001, suggesting that product innovation is positively and significantly linked with firm-level employment. They do not find any significant impact of process innovation on employment dynamics, after controlling for investment and sectorial patterns. Crespi and Tacsir (2012) focus on the impact of product and process innovation on employment in Argentina, Chile, Costa Rica, and Uruguay exploiting micro data from innovation surveys across the late 90s and 2000s. Crespi and Tacsir (2012) confirm that product innovation is significantly linked with employment growth at firm level. They observe evidence of limited labour displacement effects of process innovation in their Latin American sample.

Differently from the block of studies associated with the model by Harrison et al. (2014), other authors have implemented empirical strategies less guided by structural models to assess the relationship between product and process innovation and employment (or employment growth).

In this respect, Lachenmaier and Rottmann (2011), using a long panel dataset covering manufacturing firms in Germany for more than 20 years (1982-2002), adopt a dynamic (System-

\footnotetext{
${ }^{13}$ The core of the model was already proposed by García et al. (1998), and further refined by Jaumandreu 2003 and Peters (2004).

${ }^{14}$ Note that the negative effect of process innovation is significant in Germany and U.K., while it turns out to be generally insignificant in France and Spain.

${ }^{15}$ Hall et al. (2009) use a slightly modified version of the model by Harrison et al. (2008) and rewrite their main employment equation in terms of labor productivity.
} 
GMM) framework that takes into account not only unobserved heterogeneity, but also possible endogeneity of innovation, dynamic effects in innovative activities and in the employment adjustment process. Lachenmaier and Rottmann (2011) suggest that there are significantly positive and robust effects of innovation on employment. In contrast with previous contributions, however, they find that the (net) effect of process innovation tends to be higher in magnitude with respect to the one of product innovation 16 As pointed out by Vivarelli (2014, p. 15), "once the authors restrict their attention to (important) product innovation, which went along with patent applications, they found a highly positive and significant employment effect". However, one should note that Lachenmaier and Rottmann (2011) have very few observations for patenting process innovators.

The study by Lachenmaier and Rottmann (2011) suggests that the interaction of different indirect effects, quality differences in innovative activity and different degrees of innovation persistence might have a role in quantifying the magnitude of the firm-level relationship between innovation and employment. In this respect, using a long Spanish panel between 1990 and 2008, Triguero et al. (2014) further investigates whether firms show heterogeneous responses in employment growth depending on the degree of persistence of their different innovative activities, comparing SMEs and larger firms. Similarly to Lachenmaier and Rottmann (2011), using a System-GMM estimator, they support the existence of a positive link between persistent process innovation activities and employment growth, with the magnitude of such effect increasing with the time lag considered, especially for SMEs. Furthermore, no significant effect is found for persistence in product innovation on employment growth 17

Very few contributions analyse the effects of different types of innovation on employment growth, distinguishing among fast-growing and shrinking firms. Most recently, Herstad and Sandven (2015) link Norwegian CIS2008 data with the business register, before and after the innovation survey. Combining different approaches, including ordered logit, they investigate the relationship between employment growth prior to innovative activity, innovation output, and growth after the innovation event. Their results suggest a certain degree of autocorrelation in growth rates, and a correlation between ex-ante growth and innovative activity, which further strengthen employment growth when both product and process innovations are introduced. Furthermore, Herstad and Sandven (2015), challenging common empirical findings, suggest that process innovation is significantly associated with positive ex-post employment growth, especially for firms in the top of the distribution.

In a similar vein but focusing exclusively on small and medium enterprises in Germany, Zimmermann (2009) estimates a quantile regression model in the context of a dynamic labour demand equation, investigating the effect of product and process innovation (occurred between time $t-2$ and $t-4$ ) on two-year average employment growth rates. The findings suggest that innovation (especially process innovation) has a positive impact on employment for both growing and shrinking SMEs in Germany, with stronger effects on high-growth SMEs mostly in the case of process innovation.

Despite strong theoretical reasons - previously discussed - motivate the focus on different types of technological (product and process) innovations, an important role is also played by non-technological forms of knoweldge and in particular by organizational innovation, in shaping

\footnotetext{
${ }^{16}$ The same authors provide similar findings in a study based on the same data, using static panel methods (Lachenmaier and Rottmann 2007).

${ }^{17}$ More recently Deschryvere (2014) carries on a similar study, but mostly focused on sales growth.
} 
firm-level employment dynamics. Evangelista and Vezzani (2012) enrich previous analyses in this direction. Their estimates are based on a novel three-step approach: they first examine the impact of different innovative activities on sales growth (the so-called "innovation-induced growth process") which, they argue, is at the roots of any link between innovation and employment. Secondly, they investigate whether the innovation-induced growth process is related to positive employment effects. Finally, they assess the extent to which the positive employment effects are weakened in case firm innovative activities consists of pure process or organizational innovation 18 Evangelista and Vezzani (2012), exploiting cross-sectional CIS IV data for a selected number of European countries $[19$ confirm the existence of an innovation-induced growth process, suggesting that all innovation strategies are linked (to different extent) to sales growth. They then provide evidence that innovation strategies combining product and process innovation present the strongest positive impact on employment in manufacturing and services, while process innovation does not show any direct negative effect (unless combined with organizational innovation in manufacturing).

To sum up, a number of studies presented in this block tested explicitly the compensation mechanism via new products, generally confirming - but with some relevant exceptions - the positive role of product innovation on employment. Process innovation has instead more ambiguous effects, suggesting a complex inter-play of different forces in determining its net impact on employment dynamics. A few analyses, notably the one by Harrison et al. (2014), estimate a structural model in the attempt to separately identify the different effects associated with process innovation, in particular disentangling the price compensation mechanism and the extent to which it works in different countries. A limited number of studies analysed the persistence of different types of innovation and the peculiar role of different innovative activities over the whole conditional employment growth distribution.

\subsubsection{Firm innovation and employment over the business cycle}

The effects of (different types of) innovative activities on employment dynamics is crucially mediated by the particular phase of the economic cycle in which they occur. However, at our knowledge, limited empirical effort in recent years focused on whether the role of innovative activities on employment dynamics is mitigated or exacerbated during different phases of the business cycle, at firm level 20 A relevant exception can be found in the study by Peters et al. (2014).

Peters et al. (2014) use CIS data from 26 European countries - till the CIS 2010 wave and the German contribution to the CIS, called Mannheim Innovation Panel, to study the link between employment growth and innovation. In particular, they analyze how the effects of innovative activities on employment dynamics change during different phases of the business cycle. They emphasize the complementarity of different types of innovative activities, focusing especially on the role of product and process innovation. Furthermore, they analyse the role of technological intensity, business cycle sensitivity, size, ownership structure and location mediating the employment effects of innovation over the business cycle.

In the framework of Harrison et al. (2014), Peters et al. (2014) provide evidence that prod-

\footnotetext{
${ }^{18}$ They identify the model by means of two simultaneous structural equations (an economic performance equation and an employment equation) and estimate it using Three-Stage Least Squares (3SLS).

${ }^{19}$ Namely Czech Republic, Spain, France, Italy, Portugal and Slovenia.

${ }^{20}$ Analysis at sectoral level, such as Lucchese and Pianta (2012), are discussed in the following sections.
} 
uct innovators lead to more substantial employment growth with respect to non-innovators, as employment generated by means of higher sales of novel products more than counterbalances the negative effects associated with decreasing sales of older ones. This pattern looks stronger in periods of economic upturn and boom, when product innovation is related to increasing sales, limited job destruction due to productivity effects and to substitution between old and new products is observed. Peters et al. (2014) argue that product innovation is highly important in times of recession, as it keeps its employment-preserving effect. In manufacturing, in fact, employment losses associated with product innovators are sensibly smaller during recession than those of non-innovators. This effect seems even larger in services, where product innovators show a positive contribution to net employment growth. Additionally, Peters et al. (2014) highlight that the effects of process and organizational innovation are more limited than those of product innovation in every phase of the business cycle. In particular, in manufacturing, process and organizational innovation are linked to small labor-destroying productivity effects in upturn and downturn periods, while in booms and recession no relevant effect is identified. In services similar patterns hold, but no role is found for process innovation. Finally, the authors point out the effect of labour hoarding during recessions. In fact, the negative trend of productivity at the industry level, positively affects employment growth in such phase of the cycle. This seems to suggest that firms do not always react instantaneously to sales reduction laying off workers.

\subsection{From firms to sectors: evidence on the effect of selection on employment shares}

As already emphasized, different levels of aggregation crucially affect the way in which innovation influences employment and employment growth. Studies that focus on the relation between firm-level productivity and employment shares place at an intermediate stage between firms and industry analyses, constituting a unique trait d'union among the two. As a matter of fact, productivity and process innovation are particularly linked via the labour-saving effect associated with this type of innovative activity. This stream of literature has not been analysed in depth by previous reviews. Nested in evolutionary theory, the dynamic relation between productivity and employment shares can be well represented by means of a replicator dynamics equation. On the empirical ground, a number of productivity decompositions that are able to catch the above-mentioned relation will be discussed.

Rooted on the Schumpeterian idea that more competitive firms are able to better perform in the arena gaining market shares, one of the most used analytical tool in the evolutionary theory is the replicator dynamic equation 21

$$
\Delta s_{i, t, t-1}=\Psi s_{i, t-1}\left(\frac{\Pi_{i, t}}{\bar{\Pi}_{t}}-1\right)
$$

where

$$
\bar{\Pi}_{t}=\sum_{i} \Pi_{i, t} s_{i, t-1}
$$

Note that $s_{i, t}$ is the market share of firm $i$ which changes as a function of the ratio of the firm's productivity (or competitiveness) to the weighted average of the industry $\left(\Pi_{i, t} / \bar{\Pi}_{t}\right)$, and the $\Psi$ parameter indicates the intensity of the selection process. This equation aims at grasping the

\footnotetext{
${ }^{21}$ For a comprehensive analysis on replicator dynamics in economics see Metcalfe (1998).
} 
dynamic of market shares intertwined with firms relative performance. As a matter of fact, it aims at capturing the creative destruction process at the core of the Schumpeterian view, which postulates that best performers erode competitors market shares until they exit the market. In presence of an entry-exit process, the replicator dynamics equation will describe a pattern of endogenous sustained cyclical dynamics in market shares (see for instance Dosi et al., 1995 for a theoretical example).

Is there any relationship between firms market performance and their ability to absorb labour force? More on that, is it possible to trace a positive relationship between change in market shares and the relative amount of the employed labour force? This would be equivalent to reformulate Equation 1 as:

$$
\Delta n_{i, t, t-1}=\Psi n_{i, t-1}\left(\frac{\Pi_{i, t}}{\bar{\Pi}_{t}}-1\right)
$$

where

$$
\bar{\Pi}_{t}=\sum_{i} \Pi_{i, t} n_{i, t-1}
$$

and $n_{i, t}$ is the employment share of firm $i$.

The closest econometric analysis that has been empirically undertaken to investigate the relation between job flows and productivity is the labour productivity decomposition originally proposed by Foster et al. (1998). Note that this type of productivity decomposition discards peculiarities associated with the entry-exit process. For a recent discussion on the pros and cons of alternative decomposition methods, and more in-depth analysis of the entry and exit dynamics see Melitz and Polanec (2015). Let $\Pi_{i, t}$ be the labour productivity at time $t$ of firm $i$ and let $A P_{j, t}$ the aggregate sector productivity of firms $i$ in sector $j$ defined as ${ }^{22}$

$$
A P_{j, t}=\sum_{i \in j} \Pi_{i, t} s_{i, t}
$$

The temporal variation of sectoral aggregate productivity can be rewritten as:

$$
\begin{gathered}
\Delta A P_{j, t}=A P_{j, t}-A P_{j, t-1}= \\
\sum_{i \in j}\left(\Delta \Pi_{i} s_{i, t-1}\right)+\sum_{i \in j}\left(\Delta s_{i} \Pi_{i, t-1}\right)+\sum_{i \in j}\left(\Delta \Pi_{i} \Delta s_{i}\right)
\end{gathered}
$$

The first element represents the within component and is aimed at capturing the evolution of productivity at constant market shares: in a certain way, it grasps the learning process that occurs within the firm. The second element is the between component that represents the market selection process, tracking the time evolution of market shares holding productivity constant. The last term captures the co-variation between the two effects.

This decomposition was originally proposed to analyse the reallocation process occurring at the market level. The between effect revealed to be much weaker than the other two components, differently from what theoretically expected. Foster et al. (1998) report for U.S. data in the period 1977-1987, using labour productivity and including the variation due to net entry, that the within component accounts for $45 \%$ instead the between component for $-0.13 \%$ (this means

\footnotetext{
${ }^{22}$ Here we use the notation proposed by Bottazzi et al. (2010).
} 
that market shares move in anti-efficient direction).

In a more recent paper, Bottazzi et al. (2010), again using labour productivity but excluding the net entry component, report for Italian (1991-2004) and French (1989-2004) data a within component of $152.73 \%$ and of $89.23 \%$ and a between component of $-29.69 \%$ and a $11.79 \%$, respectively for Italy and France.

Our attention is focused on the interaction term being the latter able to catch the relation between productivity and employment growth at a midway level, in between the firm and the industry ones. For the sake of exposition, we report the value of the interaction term in the two above mentioned papers, comparing the results for output and labour shares. Differences in the time spans and methodologies used in the two studies and peculiarities associated with each productivity decomposition - with particular emphasis on measurement error and the presence of the net entry component - are to be adequately taken into account when analysing these findings. However, we believe that the qualitative juxtaposition presented in Table 1 is still valuable.

\begin{tabular}{lc}
\hline & $\begin{array}{c}\text { Interaction }(\%) \\
\sum_{i}\left(\Delta \Pi_{i} \Delta s_{i}\right)\end{array}$ \\
\hline Employment weights & \\
Italy & $-45.12 \%$ \\
France & $-84.81 \%$ \\
U.S. & $-0.11 \%$ \\
\hline Output weights & \\
Italy & $-23.04 \%$ \\
France & $-1.02 \%$ \\
U.S. & $0.37 \%$ \\
\hline
\end{tabular}

Table 1: Interaction terms. Employment and output weights. Source: Italy and France by Bottazzi et al. (2010). US by Foster et al. (1998).

One can note that the interaction term reveals to be consistently negative when employment shares are used. Interestingly, in the U.S. it changes sign from positive to negative when output shares are used in place of employment shares. This seems to suggest that - given the framework of these studies - productivity and employment shares inversely covariate, pointing to a labour saving effect of technological progress.

Baily et al. (1996) further analyse the relationship between downsizing in terms of employment and productivity growth. In particular, during the Nineties, a significant stream of empirical literature associated the substantial increase in productivity growth (33\% between 1977-1987) with the fall in employment (4.5\%) that occurred in the same time span. However, moving from aggregate to firm-level analysis, Baily et al. (1996) describe a much more complex process occurring in the U.S. market: [i] contrary to what expected, the mean establishment size only declined from 58 to 50 workers in that period; [ii] the typical plant was recorded to be very small; [iii] the typical worker used to be employed in a large plant; [iv] overall contribution to aggregate productivity growth by plants that scaled-up was qualitatively similar to the one by downsizing plants; [v] remarkable differences in terms of industry, size, ownership type and region emerged in the relation between up-downsizing and productivity growth. Furthermore, the authors carry on an interesting exercise providing a comprehensive picture of the key operating driving forces, dividing total plants into four groups: 
1. Successful upsizers $(\Delta \Pi>0 \quad \Delta s>0)$ : Plants that experienced both an increase in labour productivity and in employment shares.

2. Successful downsizers $(\Delta \Pi>0 \quad \Delta s<0)$ : Plants that experienced an increase in labour productivity but a decrease in employment shares.

3. Unsuccessful downsizers $(\Delta \Pi<0 \quad \Delta s<0)$ : Plants that experienced both a decrease in labour productivity and in employment shares.

4. Unsuccesful upsizers $(\Delta \Pi<0 \quad \Delta s>0)$ : Plants that experienced a decrease in labour productivity and an increase in employment shares.

Performing the aggregate labour productivity decomposition, they found that the first two groups similarly account for the overall increase in manufacturing productivity (2.18 and 2.56 in absolute terms respectively), compensating for the negative contribution of the other two groups. Given the presence of the interaction effect that in one case (group 1) is positive and in the other (group 2) is instead negative, the within effect of successful downsizers is stronger than the one by successful upsizers, compensating for the negative cross term. In a way, the successful upsizers, whose interaction term is positive, represent plants where the increase in productivity is accompanied by a growing demand that induce them to employ more labour force (labor absorbing firms due to the increase of final demand). An alternative explanation is that their product demand reveals high price elasticity and markets are almost perfectly competitive, such that productivity increases are transferred to final prices. On the other side, the successful downsizers, with a negative interaction term, face a constant or even declining demand, or conversely their products are characterised by a very rigid price elasticity.

Exploring a more recent dataset with the aim of measuring cross-country differences in productivity growth, Bartelsman et al. (2009) confirm the negative sign of the interaction effect. However, when the sample is split into low technology and medium-high technology industries, the large negative cross-effect reveals to markedly characterize low technology industries. On the other hand, in medium-high technology industries such effect - even tough still present - is smaller in magnitude.

On the same line Bassanini (2010), performing a cross-country analysis and splitting the data between growing and declining firms, supports the presence of a negative and highly significant cross effect (conditioning on a number of firm characteristics), which holds for both subsets of businesses. Nonetheless, when labour productivity is substituted by multi-factor productivity, the magnitude of the cross effect shrinks, becoming insignificant for almost all countries and slightly positive for growing firms in Italy, Poland, Sweden and the United Kingdom.

In order to study the process of structural change, a similar labour productivity decomposition has been carried on at sectoral level by Fagerberg (2000), who performs an extensive shift-share analysis across 24 industries in 39 market economies. This study reports a negative cross effect for almost all countries, with the notable exception of Ireland. The author clearly points out the displacing nature of technological innovation in the period under observation (1973 - 1990), where the employment creation capacity of the technologically leading industries was clearly offset by the labour displacement effect induced by productivity growth. Conversely, the traditional sectors were the ones recording higher employment shares.

The contributions discussed in this section show, once again, that the relation between (process) innovation - proxied here by productivity - and employment can twist in alternative 
directions, when different levels of aggregation are considered. In fact, in contrast with the firm-level empirical analyses - which tend to support the positive effect of product innovation but are rather inconclusive on the effect of process innovation - when productivity growth is explicitly considered as a proxy of technological progress, the labour saving component seems to prevail. Another level of complexity is added when separately examining sector-specific innovation-employment trends, further investigating the extent to which the level of aggregation matters in explaining such relationship. This will be the focus of the next section.

\subsection{Sectoral empirical evidence}

As previously emphasized, significant differences in the effects of innovative activities on employment dynamics can arise comparing the firm and the industry level of analysis. This section focuses on contributions that take, in different ways, a sectoral perspective.

In particular, some of the studies presented focus exclusively on the industry level of aggregation, trying to disentangle sectoral and technological specificities that drive differences in the innovation-employment nexus. Furthermore, other studies provide findings at sectoral level juxtaposed to firm-level analysis. Those studies allow, at least to some extent, to compare divergent trends that occur at different level of aggregations. Recent analyses that take this approach are presented in the following. A limited number of empirical applications investigate, instead, the extent to which sectoral peculiarities hold in different phases of the business cycle.

\subsubsection{Sectoral specificities, Pavitt-classes and technological regimes}

The analysis of sectoral trends in innovation and employment is long standing, including contributions by Vivarelli et al. (1996), Sirilli and Evangelista (1998) and Antonucci and Pianta (2002). A number of recent studies carry on analyses exclusively at industry level, focusing on the specificities of different technological regimes and sectoral systems of innovation (as conceptualized by Malerba, 2002 and Malerba and Orsenigo, 1993).

In this respect, Mastrostefano and Pianta (2009) investigate the effect of innovation on employment at industry level, proposing a set of dynamic models in which employment changes are explained by changes in demand (in terms of value added), in wages, in the diffusion of innovation (proxied by the share of innovative firms) and in the economic impact (in terms of turnover share) of new products. They test different specifications of the model using CIS 2 and CIS 3 data of 10 manufacturing sectors in 10 European countries, between 1994 and 2001. Overall results suggest a positive contribution of demand growth, a negative role of wage changes (which disappears when longer lags are considered), limited effects of the general diffusion of innovation (probably associated with the dominance of process innovation behaviour) and a positive role of the market impact of product innovation, only in high-innovation industries.

Bogliacino and Pianta (2010) further investigate the relationship between innovation and employment at industry-level in eight European countries, between 1994 and 2004 using CIS 2, 3 and 4 data. They analyse the effect of cost competitiveness (CC) (rooted in process innovation) and technological competitiveness (TC) (rooted in product innovation) on employment change (see also Pianta, 2001) differentiating manufacturing and services sectors according to a revised Pavitt taxonomy (see Pavitt, 1984 and Archibugi, 2001 for a review). They estimate an industrylevel labour demand curve including $C C, T C$, labour compensation, industrial dynamism and productivity growth as controls. Their results suggest that $C C$ has negative impacts on em- 
ployment changes while $T C$ has a positive role. Furthermore, their findings highlight a negative wage effect and a positive dynamism effect. However, they argue that significant differences across the Pavitt classes confirm that innovative strategies vary across sectors and that peculiar mechanisms are at work in each class, as a result of specific technological, demand and labour market factors.

Buerger et al. (2012), instead, take a regional perspective, investigating the lead-lag relation between changes in innovativeness (proxied by patents and R\&D) and employment in Germany, between 1999 and 2005. They focus on the role of agglomeration economies in different regions for four industries ${ }^{23}$ By means of a Vector Autoregressive approach, Buerger et al. (2012) confirm that the co-evolution of innovation and employment growth rates tends to be sector-specific. In the transport equipment industry (which has low patent propensity and is highly agglomerated) patent growth does not show any relation with subsequent employment growth. Instead, in the chemical industry a (weak) negative relationship is found (which suggests the presence of business stealing effects). On the other hand, in the electrics and medical instrument industries, their results point out a positive and significant association between growth of patenting and subsequent employment growth. Finally, Buerger et al. (2012) highlight that in chemicals and transport equipment industries employment growth is associated with subsequent R\&D growth.

Analyses presented in this block emphasized the role of sectoral specificities, in particular technological characteristics, agglomeration, prevalence of product or process innovation, and the extent to which they mediate the innovation-employment relation at sectoral level. Further discussion on how sectoral specificities can be reconciled with the firm-level evidence is carried on in the following.

\subsubsection{Reconciling firm-level and industry-level findings}

Studies discussed in the previous subsection focused exclusively on the sectoral level of analysis, identifying sector-specific trends associated with industry characteristics. Interestingly, a number of empirical investigations compared instead different level of aggregations, shedding further light on the different dynamics peculiar to firms and sectors.

Using a sample of French firms between 1986 and 1990, Greenan and Guellec (2000) analyse job flows indicators in the spirit of Davis and Haltiwanger (1992) and estimate a structural model in which product innovation affects the demand function and process innovation changes the production function. They suggest that, at the firm-level, process innovation contributes more than product innovation to employment growth. Furthermore, Greenan and Guellec (2000) calculate sector-level innovation indicators for a group of 37 sectors in the manufacturing industry, in order to investigate whether technical change contributes to within and between sector job reallocation. Their findings suggest that innovation is positively related to employment expansion in sectors. Distinguishing among product and process innovation, they suggest that industry-level employment benefits instead more from product innovation. They also highlight, examining excess job reallocation patterns, that product innovation contributes to within sectors job reallocation presumably by reallocating market shares between competing firms. They reconcile different effects at firm and sector-level using a selection argument: process innovation generates job creation at the expenses of competitors while product innovation has more

\footnotetext{
${ }^{23}$ Namely, chemicals; manufacturers of transport equipment; electrics and electronics; and manufacturers of medical, optical and precision instruments.
} 
moderate effects, but does not harm other firms in the sector.

Taking a similar perspective, Meriküll (2010) investigates the effect of product and process innovation on employment in Estonia, linking a panel from CIS 3 and 4 to the Business register 24 By means of dynamic panel estimations, results suggest that product innovation has milder effects at firm level while (using OLS) it has substantial positive effects at industry level. Furthermore, Meriküll (2010) highlights that process innovation has a (weakly) significantly positive effects at the firm level (in the medium and low tech subsample). However, when the analysis is carried on at the industry level, such effect tends to vanish. These findings, focused on a transition economy, generally confirm the analysis proposed by Greenan and Guellec (2000) on France.

Focusing instead on services, Evangelista and Savona (2003) investigate the employment impact of innovation, with data from the second wave of the Italian Community Innovation Survey (1993-1995). The authors estimate a binary logit model taking advantage - differently from most contributions - of a qualitative variable in the survey that assesses the impact of innovation on employment (positive or negative-nil). The authors suggest that, at firm-level, most innovative companies are more likely to exhibit a positive innovation-total employment relation, when innovative strategies are focused on the introduction of new services, internal generation of knowledge, acquisition of know-how or marketing. Sectoral patterns and technological regimes have an important role influencing the innovation-employment nexus. As a matter of fact, when shifting the focus of analysis to a more aggregate sectoral level, the positive link remains evident only for science and technology-based sectors (such as $R \& D$, technical consultancy, computing and software), while reverses in ICT-using (such as financial services or insurances) and technology-using (such as retail trade and transportation) industries. These findings reflect not only the peculiarity of the Italian model of specialization in services 25 but also confirm the differences associated with business stealing, market expansion and selection at more aggregate levels.

Finally, the previously presented study by Harrison et al. (2014) further highlights the role of industry specificities in the four countries under analysis (France, Germany, the U.K. and Spain). In particular, the authors report a lower rate of innovation in the service sector, with respect to the manufacturing sector. However, independently from the degree of innovativeness, the service sector exhibits higher average employment growth. In the context of this section, the structural model by Harrison et al. (2014) allows the authors to estimate counterfactual industry-specific market expansion and business stealing effects, providing an attempt to link the firm and sectoral levels of aggregation. The findings by Harrison et al. (2014) seem to be in favour of an overall positive effect of new products. According to their estimates, the maximum amount of business stealing in net employment growth of product innovators is about one third, while the maximum amount that is reasonable to consider as market expansion employment creation is slightly higher. Such results depend on assumptions concerning the specific demandcreation effect of the new products. One should note that the period examined by Harrison et al. (2014) generally corresponds to a positive phase of the business cycle (1998-2000).

Studies presented in this block have tried to adopt a somehow comparative perspective, with a focus on similarities and differences between firm-level and industry-level findings. Selection dynamics seem to play an important role in this context, with business stealing effects associated

\footnotetext{
${ }^{24}$ Differently from Lachenmaier and Rottmann (2011) the author does not exploit an annual innovation survey.

${ }^{25} \mathrm{In}$ particular the authors refer to the Italian de-specialization in knowledge-intensive services.
} 
mostly with process innovation. This suggests that industry-level employment might benefit more from product innovations in the sector (even though such association might be milder at the firm-level). In the following, a few sectoral analyses that investigate the extent to which the innovation-employment nexus changes along the economic cycle are presented.

\subsubsection{Innovation, employment and the business cycle at sectoral level}

The role of the business cycle mediating the impact of innovation on employment dynamics at the firm-level has been presented in Section 3.1.3. At the micro-level, a particularly important role of product innovation emerged, especially during upturns and booms, but also during recessions (employment-preserving).

At the sectoral level, Lucchese and Pianta (2012) investigate how economic cycles affect the relationship between innovation and employment in manufacturing. The authors analyze at two digit industry level - whether upswings and downswings alter the possibility of taking advantage of technological opportunities and how the cycle influences employment dynamics. Their investigation takes into account 21 manufacturing sectors from 1995 to 2007 in Germany, France, Italy, the U.K., the Netherlands and Spain, combining CIS (2, 3 and 4) data together with the OECD Structural Analysis Database (STAN). They propose a model that uses proxies for technological and cost competitiveness, exports, demand and changes in labour compensation to explain employment changes at industry-country level, allowing their estimates to vary in different phases of the business cycle (upswings and downswings).

Lucchese and Pianta (2012) suggest that innovation-based growth and employment dynamics operate in significantly different ways over the phases of the business cycle. More precisely, they show that in upswings job creation is enhanced by product innovation and exports, while reduced by high growth of wages. Conversely, during downswings the role of new products and exports becomes insignificant, while job losses are associated with process innovation ${ }^{26}$ together with high wage dynamics. Lucchese and Pianta (2012) argue that during contractions, job losses are related to the restructuring of industries, especially where labour-saving new processes are more widespread. The job creating effect of product innovation vanishes and exports contract faster than jobs. Furthermore, in downswings, the negative relation existing between employment change and wages looks stronger.

\subsection{Empirical evidence: challenges and limitations}

A substantial number of recent empirical studies - between firm and sectoral levels of aggregation - have been reviewed in Sections 3.1, 3.2 and 3.3. A critical focus on the challenges and limitations of such analyses, together with a few interesting avenues for further research, is presented in the following.

Firstly, innovative activity reveals to be an intrinsically complex phenomenon. Using different innovation proxies, ranging from patents to $R \& D$ expenditures or innovation dummies, is a clear challenge and substantially constrains the extent to which econometric analyses reflect empirical regularities. Many of the micro-econometric studies presented rely on innovation survey data, which provide a comprehensive outlook of firm's innovative activities, but also suffer from a considerable number of drawbacks. In fact, CIS-like data are typically self-reported records

\footnotetext{
${ }^{26}$ Proxied by expenditure in innovative machines.
} 
which might be particularly subject to measurement errors and anonymisation challenges. Furthermore, they often do not include comprehensive information on firm characteristics, suffer from selection problems depending on specific sample representativeness and generally focus only on continuing businesses (see Mairesse and Mohnen, 2010 for further discussion).

A number of micro-econometric studies that investigate the firm-level impacts of innovation on employment exploit the model by Harrison et al. (2014). Such methodology has clear advantages, focusing on different kinds of innovation, allowing the separate identification of the price compensation mechanisms and the estimation of conterfactual industry-level effects. However, identification and consistent estimation of the parameters of the employment growth equation proposed by Harrison et al. (2014) by means of CIS data involves few critical assumptions, related to the use of a production function setting (see Atkinson and Stiglitz, 1969, Nelson and Winter, 1982 and Dosi and Grazzi, 2006). In particular, coefficients estimates in the baseline firm-level specification refer to the difference between employment growth and old products' sales growth. Secondly, in order to deal with endogeneity issues associated with idiosyncratic productivity shocks, the model passes from a firm-specific to an average industry specification to assess the implications of estimated effects on employment growth.

A more extensive and systematic effort should be devoted to linking firms and industry dynamics, with particular references to the selection process. Not only indirect analyses of the cross effect between productivity and employment shares, but additional direct estimations should be undertaken. Moreover, empirically investigating the relevance of the replicator dynamics (Cantner and Krüger, 2008, Cantner et al., 2012, and Dosi et al., 2015) could shed further light both on selection and learning processes occurring in markets. Linking innovation and employment dynamics with profitability seems also a fruitful avenue for further research in this direction. Further analysis would be crucial to understand the way in which aggregation influences the innovation-employment nexus.

Despite many empirical studies build upon the Schumpeterian distinction between product and process innovation, the components of these innovative activities are rarely discussed in depth. Reference definitions come from the OECD Oslo manual (OECD and Eurostat, 2005). Product innovation generally includes both new or significantly improved goods and services. While process innovation encompasses new or significantly improved methods of production, delivery methods, changes in techniques, equipment or software, and can be apt to quality increase or cost decrease. Different building blocks of product and process innovation can have peculiar effects on employment dynamics. For instance, the introduction of a new delivery system could require more workers, despite being a process innovation. Furthermore, the role of software and information systems can be ambiguous (and is widely discussed in the literature that debates on the skill-biased technical change hypothesis, see for instance Autor et al., 2003). This also seems a promising avenue for further research.

More systematic investigation on the role of product and process innovation - distinguishing fast-growing and shrinking firms - would be interesting to further corroborate the results of the few studies presented, in the light of the extent to which indirect effects might vary along the conditional employment growth distribution.

The number of firm-level studies that analyse the relationship between innovation persistence and employment growth is very limited. Further exploration on this topic seems an interesting avenue for further research. In this framework, however, whenever time invariant individual 
fixed effects are included in econometric models, the identification of the impact of innovation on employment will be limited to those firms for which innovation is time variant.

Some authors (explicitly or implicitly) claim that one level of aggregation is better than the other in order to assess the innovation-employment nexus. In our view, analyses carried on at each level of aggregation, using different methodologies, are able to offer a different piece of the puzzle. Firm-level analysis are not able to catch business stealing and market expansion effects, but provide a detailed overview of innovative activities at the micro level. Sectoral analysis are able to grasp such dynamics but overlook inter-sectoral linkages and complementaries, which would be only caught at a macro-economic level, which is left out of the scope of this survey.

\section{Some stylized facts}

This work has analysed the relationship between innovation - in its declinations - and employment at different levels of aggregation. The manifold nature of technical change and the complexity of its interaction with employment dynamics have proven to characterize a large part of the evidence examined.

In this section a few stylized facts emerging from the most recent empirical evidence analysed are presented. Since the level of aggregation at which the relationship between innovation and employment is assessed has proven to be crucial, we will maintain this distinction also in the presentation of the stylized facts.

SF1 Recent firm-level analyses suggest a generally positive association of innovation (proxied by R\&D intensity or, in fewer studies, by patenting activity) with employment growth. This seems particularly true when the attention is focused on high-growth, high-technology firms, especially in more innovative economies.

SF2 Different types of innovation have specific effects on firms' employment dynamics. In a general framework of complementarity 27 the distinction between product and process innovation confirms to be theoretically fruitful.

SF3 Most empirical studies highlight the positive role of product innovation at the microeconomic level, notwithstanding the cannibalization of old products, which rarely appears to completely counterbalance the direct association with job creation. The effects of process innovation are, instead, more controversial. As a matter of fact, they are the outcome of interacting forces, notably the labour saving direct effect (under fixed output) and the indirectly positive effect (mainly associated with the price compensation mechanism). Recent evidence presented points to a generally non-negative role of process innovation at microeconomic level, suggesting that the direct effect does not always prevail on other counteracting forces. In this respect, it is worth recalling that few studies are able to account for competitive dynamics occurring at market/sectoral level. A positive role of process innovation at firm level might often hinder different degrees of job displacement at industry level, when such effects are not estimated.

\footnotetext{
${ }^{27}$ Note that descriptive statistics presented by Peters et al. (2014) and Harrison et al. (2014) suggest that the share of firms carrying on both product and process innovation is higher than the shares of only-product or only-process innovators.
} 
SF4 Comparing the magnitude of the effects across economies is not obvious and depends on country specificities, technological characteristics, differences in the competitive arena and on the extent to which different compensation mechanisms work.

SF5 A trait d'union between firm-level and industry-level studies is offered by those analyses that break productivity and employment changes by means of shift-and-share decompositions. The major part of these studies tend to show a negative covariation of process innovations (proxied by productivity) with employment shares. Methodological caveats related to specific decompositions used apply when analysing such results.

SF6 Sectoral analyses examined tend to highlight a positive effect of innovation on employment. However, sectoral specificities and technological characteristics, including orientation to product or process innovation, prove - again - to be important in driving such relationship.

SF7 Some studies support the idea that the magnitude of the effect of process innovation on employment is significantly reduced when analyses are carried on at sectoral level. This derives also from the role of competitive dynamics - such as business stealing - that become observable at this level of aggregation. One should note that these forces are counterbalanced by the diffusion of technologies in the industry, which can operate as sectoral analogous to the price compensation mechanism. Product innovation, instead, generally confirms to be positively related to sectoral employment expansion and seems therefore a more important driving force at industry level. Such positive effect also benefits from market expansion, i.e. the extent to which product innovators are able to attract new adopters. Different effects of product and process innovation - at firm and sectoral level - are schematically presented in Table 2 in Appendix.

\section{Concluding remarks: we know (what) we don't know}

The number, variety, and scope of the studies that have been reviewed reveal the recent developments in the conceptualization and empirical analysis of the effects of innovation and technical change on employment dynamics. A number of themes can be considered as developments on insights already present in the contributions of classical economists (including Marx and Ricardo) and, after them, Schumpeter and Keynes. Other elements of investigation - and their declinations over the different levels of aggregation - enriched the understanding of the innovation-employment nexus.

This work departs from previous analyses in different respects: [i] it significantly extends and discusses most recent firm-level and industry-level contributions, focusing on the last decade since 2000, with particular attention to differences in methodologies and limitations; [ii] it emphasizes the impact of the aggregation level on the innovation-employment nexus; [iii] it investigates in detail the extent to which compensation mechanisms operate at firm and industry level; [iv] it discusses the firm-industry linkage integrating results from shift and share decompositions of productivity on employment shares; [v] it focuses on the effect of business cycles, and on how they mediate the innovation-employment relationship.

A number of stylised facts have been presented in the previous section, disentangling the extent to which innovative activities are associated with employment or its growth, at different levels of aggregation. Limitations associated with some of the empirical studies have been also 
discussed throughout this essay.

Let us emphasize that the analysis carried on, despite rich in a number of dimensions, is far from being exhaustive. Indeed, it does not cover the whole set of possible domains that are relevant to have a comprehensive view on the technology-employment nexus. In particular, let us point out a number of issues that we left out of the scope of the current survey 28

Limited attention has been devoted to the role of non-technological and organizational innovation and of mutation of work practices (e.g. lean production, team working, job rotation, total quality management), despite these dimensions are important determinants of firm performance and exhibit clear complementarity with other innovative activities.

Part of this essay analysed the association between productivity (as a proxy of process innovation) and employment, focusing especially on a number of studies based on shift-andshare decompositions. However, very limited attention has been devoted to the extent to which different types of innovation are related to productivity growth. A very wide stream of the literature focuses on such relationship (see for instance Hall, 2011 or Mohnen and Hall, 2013 for surveys and Crépon et al., 1998 or Griffith et al., 2006 for econometric models) which surely affects the innovation-employment nexus.

The role of international trade, export and integration in the global value chain are likely to play a prominent role - at different levels of aggregation - in influencing the extent to which innovation is associated with employment growth (see for instance Dosi et al., 1990). Exporting firms might benefit from a learning effect (Baldwin and Gu, 2003). Furthermore, routinization and automation might well be particularly linked to the extent to which jobs are off-shorable (in the sense that more routinized activities might be among the ones more subject to be relocated or de-localised), with effects not only on the quality of employment but also on its quantity (see also Marcolin et al., 2016). Furthermore, national patterns of specialization into different industries (for instance more prone to product or process innovation) may also affect the innovation-employment relation at a more aggregate level. All the above mentioned effects might well be different in catching-up versus developed economies.

Despite emphasizing the role of country specificities, we did not devote systematic attention to the analysis of the impacts of institutional factors on the innovation-employment relation. The regulatory framework - especially in terms of employment protection legislation, minimum wage settings, access to finance and the strength of collective bargaining - was not taken into account in most studies presented but crucially affects the employment-innovation nexus (see for instance Andrews et al., 2014 or Giuliodori and Stucchi, 2012). Furthermore, the features of national innovation systems (Freeman, 2002) were not discussed in detail, despite playing a key role among the country-specific determinants of the impact of innovation on employment.

Additionally, few recent analyses that look at the extent to which robotization and automation affect employment are particularly related to this study (see for instance Graetz and Michaels, 2015). The role of innovation and automation on the quality of workers has been kept outside the scope of this essay, disregarding the presence of relevant compositional effects in the extent to which innovative activities influence the demand for skills. In particular, a wide stream of literature debates on the presence of routinized skill-biased technical change (see Autor, 2015) and on whether decrease in demand of medium-skilled workers is associated with the so-called jobless recovery, in the aftermath of the Great Recession (Jaimovich and Siu, 2012).

\footnotetext{
${ }^{28}$ Of course - despite our effort - this list should not be considered as exhaustive.
} 
Extending the analysis towards a more comprehensive view, bridging the gap with the missing pieces of the puzzle - with particular reference to the firm-wage dynamics, the transformation of the shop floor, the effects of trade and international competition and the policy-institutional factors - would be a natural continuation of this work.

\section{References}

Abernathy, W. J. and J. M. Utterback (1978). Patterns of industrial innovation. Technology Review 64(7), $254-228$.

Andrews, D., C. Criscuolo, and C. Menon (2014). Do resources flow to patenting firms?: Cross-country evidence from firm level data. OECD Economics Department Working Papers No. 1127, OECD Publishing.

Antonucci, T. and M. Pianta (2002). Employment effects of product and process innovation in Europe. International Review of Applied Economics 16(3), 295-307.

Archibugi, D. (2001). Pavitt's taxonomy sixteen years on: a review article. Economics of Innovation and New Technology 10(5), 415-425.

Atkinson, A. B. and J. E. Stiglitz (1969). A new view of technological change. The Economic Journal $79(315), 573-578$.

Autor, D. (2015). Why are there still so many jobs? The history and future of workplace automation. The Journal of Economic Perspectives 29(3), 3-30.

Autor, D., F. Levy, and R. Murnane (2003). The skill content of recent technological change: An empirical exploration. The Quarterly Journal of Economics 118(4), 1279-1333.

Baily, M. N., E. J. Bartelsman, and J. Haltiwanger (1996). Downsizing and productivity growth: myth or reality? Small Business Economics 8(4), 259-278.

Baldwin, J. R. and W. Gu (2003). Export-market participation and productivity performance in Canadian manufacturing. Canadian Journal of Economics/Revue canadienne d'économique 36(3), 634-657.

Bartelsman, E., J. Haltiwanger, and S. Scarpetta (2009). Measuring and analyzing cross-country differences in firm dynamics. In T. Dunne, J. B. Jensen, and M. J. Roberts (Eds.), Producer dynamics: New evidence from micro data, pp. 15-76. Chicago: University of Chicago Press.

Bassanini, A. (2010). Inside the perpetual-motion machine: cross-country comparable evidence on job and worker flows at the industry and firm level. Industrial and Corporate Change 19(6), 2097-2134.

Baumol, W. (1967). Macroeconomics of unbalanced growth: the anatomy of urban crisis. The American Economic Review 57(3), 415-426.

Benavente, J. M. and R. Lauterbach (2008). Technological innovation and employment: complements or substitutes? The European Journal of Development Research 20(2), 318-329.

Bessen, J. (2015). Learning by Doing: The Real Connection Between Innovation, Wages, and Wealth. Yale: Yale University Press.

Bogliacino, F. and M. Pianta (2010). Innovation and employment: a reinvestigation using revised Pavitt classes. Research Policy 39(6), 799-809.

Bogliacino, F., M. Piva, and M. Vivarelli (2012). R\&D and employment: An application of the LSDVC estimator using European microdata. Economics Letters 116(1), 56-59. 
Bottazzi, G., G. Dosi, N. Jacoby, A. Secchi, and F. Tamagni (2010). Corporate performances and market selection: some comparative evidence. Industrial and Corporate Change 19(6), 1953-1996.

Boyer, R. (1988). Technical change and theory of 'régulation'. In G. Dosi, C. Freeman, R. Nelson, G. Silverberg, and L. Soete (Eds.), Technical change and economic theory. London and New York: Pinter Publisher.

Brouwer, E., A. Kleinknecht, and J. O. Reijnen (1993). Employment growth and innovation at the firm level. Journal of Evolutionary Economics 3(2), 153-159.

Bruno, G. S. (2005). Approximating the bias of the LSDV estimator for dynamic unbalanced panel data models. Economics Letters 87(3), 361-366.

Buerger, M., T. Broekel, and A. Coad (2012). Regional dynamics of innovation: Investigating the coevolution of patents, research and development (R\&D), and employment. Regional Studies 46(5), $565-582$.

Cantner, U. and J. Krüger (2008). Micro-heterogeneity and aggregate productivity development in the German manufacturing sector. Journal of Evolutionary Economics 18(2), 119-133.

Cantner, U., J. Krüger, and R. Söllner (2012). Product quality, product price, and share dynamics in the German compact car market. Industrial and Corporate Change 21(5), 1085-1115.

Clark, C. (1957). The conditions of economic progress. London: Macmillan.

Coad, A. and R. Rao (2011). The firm-level employment effects of innovations in high-tech US manufacturing industries. Journal of Evolutionary Economics 21(2), 255-283.

Cohen, A. J. and G. C. Harcourt (2003). Retrospectives: Whatever happened to the Cambridge capital theory controversies? The Journal of Economic Perspectives 17(1), pp. 199-214.

Crépon, B., E. Duguet, and J. Mairesse (1998). Research, innovation and productivity: An econometric analysis at the firm level. Economics of Innovation and New Technology 7(2), 115-158.

Crespi, G. and E. Tacsir (2012). Effects of innovation on employment in Latin America. IDB Technical Note No. 496, Inter-American Development Bank.

Davis, S. J. and J. Haltiwanger (1992). Gross job creation, gross job destruction, and employment reallocation. The Quarterly Journal of Economics 107(3), 819-63.

Deschryvere, M. (2014). R\&D, firm growth and the role of innovation persistence: an analysis of Finnish SMEs and large firms. Small Business Economics 43(4), 767-785.

Dosi, G. (1982). Technological paradigms and technological trajectories: a suggested interpretation of the determinants and directions of technical change. Research policy 11(3), 147-162.

Dosi, G. (1984). Technology and conditions of macroeconomic development. In C. Freeman (Ed.), Design, Innovation and Long Cycles in Economic Development, pp. 99-125. London: Design Research Publications.

Dosi, G. (1988). Sources, procedures, and microeconomic effects of innovation. Journal of Economic Literature 26(3), 1120-1171.

Dosi, G., C. Freeman, R. Nelson, G. Silverberg, and L. Soete (1988). Technical change and economic theory. London and New York: Pinter Publisher. 
Dosi, G. and M. Grazzi (2006). Technologies as problem-solving procedures and technologies as input-output relations: some perspectives on the theory of production. Industrial and Corporate Change 15(1), 173-202.

Dosi, G., M. Grazzi, L. Marengo, and S. Settepanella (2016). Production theory: accounting for firm heterogeneity and technical change. The Journal of Industrial Economics (forthcoming).

Dosi, G., O. Marsili, L. Orsenigo, and R. Salvatore (1995). Learning, market selection and the evolution of industrial structures. Small Business Economics 7(6), 411-436.

Dosi, G., D. Moschella, E. Pugliese, and F. Tamagni (2015). Productivity, market selection, and corporate growth: comparative evidence across US and Europe. Small Business Economics 45(3), 1-30.

Dosi, G. and R. R. Nelson (2010). Technical change and industrial dynamics as evolutionary processes. In B. H. Hall and N. Rosenberg (Eds.), Handbook of the Economics of Innovation, Volume 1, pp. 51-127. Amsterdam: North-Holland.

Dosi, G., K. Pavitt, and L. Soete (1990). The economics of technical change and international trade. New York: New York University Press.

Evangelista, R. and M. Savona (2003). Innovation, employment and skills in services. Firm and sectoral evidence. Structural Change and Economic Dynamics 14(4), 449-474.

Evangelista, R. and A. Vezzani (2012). The impact of technological and organizational innovations on employment in European firms. Industrial and Corporate Change 21(4), 871-899.

Fagerberg, J. (2000). Technological progress, structural change and productivity growth: a comparative study. Structural Change and Economic Dynamics 11(4), 393-411.

Foster, L., J. Haltiwanger, and C. Krizan (1998). Aggregate productivity growth: Lessons from microeconomic evidence. In C. R. Hulten, E. R. Dean, and M. J. Harper (Eds.), New Developments in Productivity Analysis. Chicago: University of Chicago Press.

Freeman, C. (2002). Continental, national and sub-national innovation systems - complementarity and economic growth. Research policy 31(2), 191-211.

Freeman, C., J. Clark, and L. Soete (1982). Unemployment and technical innovation. London and New York: Pinter Publisher.

Freeman, C. and C. Perez (1988). Structural crises of adjustment: business cycles and investment behaviour. In G. Dosi, C. Freeman, R. Nelson, G. Silverberg, and L. Soete (Eds.), Technical Change and Economic Theory. London and New York: Pinter Publisher.

Freeman, C. and L. Soete (1994). Work for All or Mass Unemployment? Computerised Technical Change into the 21st Century. London and New York: Pinter Publisher.

García, A., J. Jaumandreu, and C. Rodríguez (1998). Innovation and jobs at the firm level. Documento de Trabajo No. 9810, Programa de Investigaciones Economicas.

Giuliodori, D. and R. Stucchi (2012). Innovation and job creation in a dual labor market: evidence from Spain. Economics of Innovation and New Technology 21(8), 801-813.

Graetz, G. and G. Michaels (2015). Robots at work. CEPR Discussion Paper No. DP10477, Centre for Economic Policy Research.

Greenan, N. and D. Guellec (2000). Technological innovation and employment reallocation. Labour 14(4), $547-590$ 
Greenhalgh, C., M. Longland, and D. Bosworth (2001). Technological activity and employment in a panel of UK firms. Scottish Journal of Political Economy 48(3), 260-282.

Griffith, R., E. Huergo, J. Mairesse, and B. Peters (2006). Innovation and productivity across four European countries. Oxford Review of Economic Policy 22(4), 483-498.

Hall, B. H. (1987). The relationship between firm size and firm growth in the US manufacturing sector. The Journal of Industrial Economics 35(4), 583-606.

Hall, B. H. (2011). Innovation and productivity. NBER Working Papers No. 17178, National Bureau of Economic Research.

Hall, B. H., F. Lotti, and J. Mairesse (2009). Innovation and productivity in SMEs: empirical evidence for Italy. Small Business Economics 33(1), 13-33.

Harrison, R., J. Jaumandreu, J. Mairesse, and B. Peters (2008). Does innovation stimulate employment? A firm-level analysis using comparable micro-data from four European countries. NBER Working Paper No. 14216, National Bureau of Economic Research.

Harrison, R., J. Jaumandreu, J. Mairesse, and B. Peters (2014). Does innovation stimulate employment? A firm-level analysis using comparable micro-data from four european countries. International Journal of Industrial Organization 35, 29-43.

Herstad, S. J. and T. Sandven (2015). Innovation and corporate employment growth revisited. Papers in Innovation Studies No. 2015/3, Lund University, CIRCLE-Center for Innovation, Research and Competences in the Learning Economy.

Hildenbrand, W. (1981). Short-run production functions based on microdata. Econometrica 49(5), $1095-1125$.

Hölzl, W. (2009). Is the R\&D behaviour of fast-growing SMEs different? Evidence from CIS III data for 16 countries. Small Business Economics 33(1), 59-75.

Jaimovich, N. and H. E. Siu (2012). The trend is the cycle: Job polarization and jobless recoveries. NBER Working Paper No. 18334, National Bureau of Economic Research.

Jaumandreu, J. (2003). Does innovation spur employment? A firm-level analysis using Spanish CIS data. Mimeo.

Keynes, J. M. (1931). Economic possibilities for our grandchildren. In Essays in persuasion, pp. 358-73. London: Macmillan \& Co.

Keynes, J. M. (1963). A self-adjusting economic system. Nebraska Journal of Economics and Business 2(2), 11-15.

Klette, J. and S. E. Førre (1998). Innovation and job creation in a small open economy - evidence from Norwegian manufacturing plants 1982-92. Economics of Innovation and New Technology 5(2-4), $247-272$.

Kondratieff, N. and W. Stolper (1935). The long waves in economic life. The Review of Economics and Statistics 17(6), 105-115.

Kuznets, S. (1955). Economic growth and income inequality. The American Economic Review 45(1), $1-28$.

Lachenmaier, S. and H. Rottmann (2007). Employment effects of innovation at the firm level. Jahrbücher für Nationalökonomie und Statistik 227(3), 254-272. 
Lachenmaier, S. and H. Rottmann (2011). Effects of innovation on employment: A dynamic panel analysis. International Journal of Industrial Organization 29(2), 210-220.

Landesmann, M. and K. Pichelmann (1999). Employment patterns and the welfare services sector. In M. Landesmann and K. Pichelmann (Eds.), Unemployment in Europe, pp. 205-231. London: Macmillan.

Lazonick, W. (2011). Reforming the financialized business corporation. Mimeo.

Lucchese, M. and M. Pianta (2012). Innovation and employment in economic cycles. Comparative Economic Studies 54(2), 341-359.

Mairesse, J. and P. Mohnen (2010). Using innovation surveys for econometric analysis. In B. H. Hall and N. Rosenberg (Eds.), Handbook of the Economics of Innovation, Volume 2, pp. 1129-1155. Amsterdam: North-Holland.

Malerba, F. (2002). Sectoral systems of innovation and production. Research Policy 31(2), 247-264.

Malerba, F. and L. Orsenigo (1993). Technological regimes and firm behavior. Industral and Corporate Change 2(1), 45-71.

Marcolin, L., S. Miroudot, and M. Squicciarini (2016). Routine jobs, employment and technological innovation in global value chains. OECD Science, Technology and Industry Working Papers No. 2016/01, OECD Publishing.

Mastrostefano, V. and M. Pianta (2009). Technology and jobs. Economics of Innovation and New Technology 18(8), 729-741.

Melitz, M. J. and S. Polanec (2015). Dynamic Olley-Pakes productivity decomposition with entry and exit. The RAND Journal of Economics 46(2), 362-375.

Meriküll, J. (2010). The impact of innovation on employment: firm-and industry-level evidence from a catching-up economy. Eastern European Economics 48(2), 25-38.

Metcalfe, J. S. (1998). Evolutionary Economics and Creative Destruction. New York: Routledge.

Mohnen, P. and B. H. Hall (2013). Innovation and productivity: an update. Eurasian Business Review 3(1), 47-65.

Nelson, R. R. and S. G. Winter (1982). An evolutionary theory of economic change. Cambridge, MA: Harvard University Press.

OECD and Eurostat (2005). Oslo Manual: Guidelines for Collecting and Interpreting Innovation Data, 3rd Edition. The Measurement of Scientific and Technological Activities, OECD Publishing.

Pasinetti, L. L. (1983). Structural change and economic growth: a theoretical essay on the dynamics of the wealth of nations. Cambridge, UK: Cambridge University Press.

Pavitt, K. (1984). Sectoral patterns of technical change: towards a taxonomy and a theory. Research policy $13(6), 343-373$.

Peters, B. (2004). Employment effects of different innovation activities: Microeconometric evidence. ZEW Discussion Papers No. 04-73, ZEW - Center for European Economic Research.

Peters, B., B. Dachs, M. Dünser, M. Hud, C. Köhler, and C. Rammer (2014). Firm Growth, Innovation and the Business Cycle. Number No. 110577. Mannheim: ZEW - Center for European Economic Research. 
Pianta, M. (2001). Innovation, demand and employment. In P. Petit and L. Soete (Eds.), Technology and the Future of European Employment, pp. 142-165. Cheltenham: Edward Elgar Publishing.

Pianta, M. (2005). Innovation and employment. In D. M. J. Fagerberg and R. Nelson (Eds.), The Oxford Handbook of Innovation, pp. 568-598. Oxford: Oxford University Press.

Piva, M. and M. Vivarelli (2005). Innovation and employment: evidence from Italian microdata. Journal of Economics 86(1), 65-83.

Pohlmeier, W. and H. Entorf (1990). Employment, innovation and export activity: Evidence from firmlevel data. In J. Florens, M. Ivaldi, J. Laffont, and F. Laisney (Eds.), Microeconometrics: Surveys and Applications, pp. 394-415. London: Basil Blackwell.

Ricardo, D. (1817). On the principles of political economy and taxation. London: John Murray.

Simonetti, R., K. Taylor, and M. Vivarelli (2000). Modelling the employment impact of innovation. In M. Vivarelli and M. Pianta (Eds.), The Employment Impact of Innovation: Evidence and Policy, pp. 26-43. London: Routledge.

Sirilli, G. and R. Evangelista (1998). Technological innovation in services and manufacturing: results from Italian surveys. Research policy 27(9), 881-899.

Smolny, W. (1998). Innovations, prices and employment: A theoretical model and an empirical application for West German manufacturing firms. The Journal of Industrial Economics 46(3), 359-381.

Spiezia, V. and M. Vivarelli (2002). Innovation and employment: A critical survey. In N. Greenan, L. Y., and J. Mairesse (Eds.), Productivity, Inequality and the Digital Economy: A Transatlantic Perspective, pp. 101-31. Cambridge, MA: MIT Press.

Stam, E. and K. Wennberg (2009). The roles of R\&D in new firm growth. Small Business Economics 33(1), 77-89.

Triguero, A., D. Corcoles, and M. C. Cuerva (2014). Persistence of innovation and firms growth: evidence from a panel of SME and large Spanish manufacturing firms. Small Business Economics 43(4), 787804 .

Utterback, J. M. and W. J. Abernathy (1975). A dynamic model of process and product innovation. Omega 3(6), 639-656.

Van Reenen, J. (1997). Employment and technological innovation: evidence from UK manufacturing firms. Journal of Labor Economics 15(2), 255-284.

Van Roy, V., D. Vertesy, and M. Vivarelli (2015). Innovation and employment in patenting firms: Empirical evidence from Europe. IZA Discussion Paper No. 9147, Institute for the Study of Labor (IZA).

Vivarelli, M. (1995). The economics of technology and employment: theory and empirical evidence. London: Edward Elgar Publishing.

Vivarelli, M. (2014). Innovation, employment and skills in advanced and developing countries: A survey of economic literature. Journal of Economic Issues 48(1), 123-154.

Vivarelli, M., R. Evangelista, and M. Pianta (1996). Innovation and employment in Italian manufacturing industry. Research policy 25(7), 1013-1026.

Yang, C. H. and C. H. Huang (2005). R\&D, size and firm growth in Taiwan's electronics industry. Small Business Economics 25(5), 477-487. 
Yasuda, T. (2005). Firm growth, size, age and behavior in Japanese manufacturing. Small Business Economics 24(1), 1-15.

Yu, X., G. Dosi, J. Lei, and A. Nuvolari (2015). Institutional change and productivity growth in China's manufacturing: the microeconomics of knowledge accumulation and creative 'restructuring'. Industrial and Corporate Change 24(3), 565-602.

Zimmermann, V. (2009). The impact of innovation on employment in small and medium enterprises with different growth rates. Jahrbücher für Nationalökonomie und Statistik 229(2/3), 313-326. 


\section{Appendix}

Table 2: Effects of product and process innovation at firm and sector level

\begin{tabular}{|c|c|c|}
\hline & Product InNOVATION & Process InNovation \\
\hline Firm Level & $\begin{array}{l}\text { Positive }(+) \\
\text { Notwithstanding Cannibalization } \\
\quad \Downarrow \\
\text { PRODUCTS COMPENSATION MECHANISM }\end{array}$ & $\begin{array}{l}\text { Directly Negative }(-) \\
\text { (Under fixed output) } \\
\\
\text { Indirectly Positive }(+) \\
\text { (Under output expansion) } \\
\Downarrow \\
\text { Price COMPENSATION MECHANISM }\end{array}$ \\
\hline Industry Level & $\begin{array}{l}\text { Business Stealing } \Rightarrow \text { No effect }(0) \\
\text { Market expansion } \Rightarrow \text { Positive }(+)\end{array}$ & $\begin{array}{c}\text { Negative (-) (also for Business Stealing) } \\
\Downarrow \\
\text { SECTORAL ShifT-Structural CHANGE } \\
\text { Indirectly Positive }(+) \\
\Downarrow \\
\text { TECHNOLOGY Diffusion }\end{array}$ \\
\hline
\end{tabular}


Table 3: Synoptic table: firm-level studies

\begin{tabular}{|c|c|c|c|c|c|}
\hline $\begin{array}{l}\text { FiRM LEVEL } \\
\text { Study }\end{array}$ & $\begin{array}{l}\text { DEPENDENT VARIABLE \& } \\
\text { PROXY FOR TECHNOLOGY }\end{array}$ & METHODOLOGY & DATA & $\begin{array}{l}\text { COUNTRY } \\
\text { (TIME PERIOD) }\end{array}$ & Results \\
\hline $\begin{array}{l}\text { Stam and } \\
\text { Wennberg (2009) }\end{array}$ & $\begin{array}{l}\text { Employment growth } \\
\& \text { R\&D }\end{array}$ & OLS & Start-up database & $\begin{array}{l}\text { The Netherlands } \\
(1994-2000)\end{array}$ & $\begin{array}{l}\text { No average effect between R\&D } \\
\text { and employment growth. } \\
(+) \text { Effect on top } 10 \% \text { and high tech }\end{array}$ \\
\hline Holzl (2009) & $\begin{array}{l}\text { Employment growth } \\
\& \text { R\&D }\end{array}$ & $\begin{array}{l}\text { Quantile Regression } \\
\text { and matching }\end{array}$ & CIS 3 & $\begin{array}{l}16 \text { Countries } \\
(1998-2000)\end{array}$ & $\begin{array}{l}\text { (+) Effect on high-growth } \\
\text { SMEs, in countries closer } \\
\text { to the technological frontier }\end{array}$ \\
\hline Bogliacino et al. (2012) & $\begin{array}{l}\text { Employment level } \\
\& \text { R\&D }\end{array}$ & LSDVC & 700 Large firms & $\begin{array}{l}\text { Europe } \\
(1990-2008)\end{array}$ & $\begin{array}{l}(+) \text { Impact of } \\
\text { R\&D on employment in services } \\
\text { and high-tech manufacturing }\end{array}$ \\
\hline Coad and Rao (2011) & $\begin{array}{l}\text { Employment growth } \\
\& \text { R\&D and patents }\end{array}$ & $\begin{array}{l}\text { OLS, WLS } \\
\text { LSDVC }\end{array}$ & $\begin{array}{l}\text { Compustat \& } \\
\text { NBER Innovation }\end{array}$ & $\begin{array}{l}\text { United States } \\
(1963-1997)\end{array}$ & $\begin{array}{l}(+) \text { Effects on employment for } \\
\text { fast-growing high-tech firms }\end{array}$ \\
\hline Van Roy et al. (2015) & $\begin{array}{l}\text { Employment growth \& } \\
\text { patent quality information } \\
\text { (forward citation) }\end{array}$ & System GMM & $\begin{array}{l}\text { Panel dataset } \\
\text { (patenting) }\end{array}$ & $\begin{array}{l}\text { Europe } \\
(2003-2012)\end{array}$ & $\begin{array}{l}\text { (+) Effect of } \\
\text { patenting activities } \\
\text { on employment but valid } \\
\text { only for high-tech } \\
\text { manufacturing sectors }\end{array}$ \\
\hline Harrison et al. (2014) & $\begin{array}{l}\text { Employment growth \& } \\
\text { Product and Process innov. } \\
\text { (old and new products) }\end{array}$ & $\begin{array}{l}\text { Structural model, } \\
\text { OLS and IV }\end{array}$ & CIS 3 & $\begin{array}{l}\text { Spain, Germany, } \\
\text { U.K. and France } \\
(1998-2000)\end{array}$ & $\begin{array}{l}\text { (-) Effect of process innovation } \\
\text { under fixed output. } \\
(+) \text { Effect of product innovation }\end{array}$ \\
\hline Hall et al. (2009) & $\begin{array}{l}\text { Employment growth \& } \\
\text { Product and Process } \\
\text { innovation }\end{array}$ & $\begin{array}{l}\text { Structural model, } \\
\text { OLS and IV }\end{array}$ & $\begin{array}{l}\text { Mediocredito- } \\
\text { Capitalia }\end{array}$ & $\begin{array}{l}\text { Italy } \\
(1995-2003)\end{array}$ & $\begin{array}{l}\text { No displacement effect } \\
\text { of process innovation. } \\
(+) \text { Effect of new and } \\
\text { old products }\end{array}$ \\
\hline $\begin{array}{l}\text { Benavente and } \\
\text { Lauterbach (2008) }\end{array}$ & $\begin{array}{l}\text { Employment growth \& } \\
\text { Product and Process } \\
\text { innovation }\end{array}$ & $\begin{array}{l}\text { Structural model } \\
\text { OLS and IV }\end{array}$ & $\begin{array}{l}\text { Micro-data } \\
\text { (surveys) }\end{array}$ & $\begin{array}{l}\text { Chile } \\
(1998-2001)\end{array}$ & $\begin{array}{l}(+) \text { Effect of product innovation. } \\
\text { No effect of process }\end{array}$ \\
\hline $\begin{array}{l}\text { Crespi and } \\
\text { Tacsir (2012) }\end{array}$ & $\begin{array}{l}\text { Employment growth \& } \\
\text { Product and Process } \\
\text { innovation }\end{array}$ & $\begin{array}{l}\text { Structural model } \\
\text { OLS and IV }\end{array}$ & $\begin{array}{l}\text { Firm level data } \\
\text { Innovation Survey }\end{array}$ & $\begin{array}{l}\text { Argentina, Chile, } \\
\text { Costa Rica, } \\
\text { and Uruguay } \\
(\text { late } 90 s-2000 s \text { ) }\end{array}$ & $\begin{array}{l}(+) \text { Effect of product, } \\
\text { no effect of } \\
\text { process innovation }\end{array}$ \\
\hline $\begin{array}{l}\text { Lachenmaier and } \\
\text { Rottmann (2011) }\end{array}$ & $\begin{array}{l}\text { Employment growth \& } \\
\text { Product and Process } \\
\text { innovation }\end{array}$ & System GMM & $\begin{array}{l}\text { Ifo Innovation Survey } \\
\text { (panel) }\end{array}$ & $\begin{array}{l}\text { Germany } \\
(1982-2002)\end{array}$ & $\begin{array}{l}(+) \text { Effect of process }> \\
\text { than product innovation }\end{array}$ \\
\hline Triguero et al. (2014) & $\begin{array}{l}\text { Employment growth \& } \\
\text { Persistent innovation }\end{array}$ & System GMM & ESEE (panel) & $\begin{array}{l}\text { Spain } \\
(1990-2008)\end{array}$ & $\begin{array}{l}(+) \text { Link between } \\
\text { persistent process innovation } \\
\text { and employment growth, no role } \\
\text { of persistent product innovation }\end{array}$ \\
\hline Herstad et al. (2015) & $\begin{array}{l}\text { Employment growth \& } \\
\text { different types } \\
\text { of innovative activities }\end{array}$ & $\begin{array}{l}\text { Ordered logit } \\
\text { (and others) }\end{array}$ & $\begin{array}{l}\text { CIS2008 } \\
\text { linked with BR }\end{array}$ & $\begin{array}{l}\text { Norway } \\
(2004-2010)\end{array}$ & $\begin{array}{l}\text { (+) Correlation between } \\
\text { ex-ante growth and } \\
\text { innovative activity. } \\
(+) \text { Effect of process } \\
\text { innovation on ex-post } \\
\text { employment growth, } \\
\text { for firms in the } \\
\text { top of the distribution }\end{array}$ \\
\hline Zimmermann (2009) & $\begin{array}{l}\text { Employment growth \& } \\
\text { Product and process } \\
\text { innovation }\end{array}$ & Quantile Regression & Panel of SMEs & $\begin{array}{l}\text { Germany } \\
(2003-2006)\end{array}$ & $\begin{array}{l}\text { (+) Effect of process innovation } \\
\text { on employment for both } \\
\text { growing and shrinking SMEs. } \\
\text { Stronger effects on } \\
\text { high-growth SMEs }\end{array}$ \\
\hline $\begin{array}{l}\text { Evangelista and } \\
\text { Vezzani }(2012)\end{array}$ & $\begin{array}{l}\text { Employment growth \& } \\
\text { Product, process } \\
\text { organizational innovation }\end{array}$ & 3SLS & CIS 4 & $\begin{array}{l}6 \text { European } \\
\text { countries } \\
(2002-2004)\end{array}$ & $\begin{array}{l}(+) \text { Effect of product and process } \\
\text { innovation on employment } \\
\text { in manufacturing and services. } \\
(-) \text { Effect of process innovation } \\
\text { when combined with } \\
\text { organizational innovation }\end{array}$ \\
\hline Peters et al. (2014) & $\begin{array}{l}\text { Employment growth \& } \\
\text { Product and process } \\
\text { innovation }\end{array}$ & $\begin{array}{l}\text { Structural model } \\
\text { OLS and IV }\end{array}$ & $\begin{array}{l}\text { CIS 3-4-2006 } \\
2008-2010\end{array}$ & $\begin{array}{l}26 \text { European Countries } \\
(1998-2010)\end{array}$ & $\begin{array}{l}(+) \text { employment growth } \\
\text { for product innovators, } \\
\text { particularly during booms. } \\
\text { Employment-preserving } \\
\text { effect of product innovation } \\
\text { during downturns. Limited } \\
\text { role of process innovation }\end{array}$ \\
\hline
\end{tabular}


Table 4: Synoptic table: cross effect in the shift-and-share decomposition

\begin{tabular}{|c|c|c|c|c|c|}
\hline StUdy & DEPENDENT VARIABLE & $\begin{array}{l}\text { SHIFT-AND-SHARE } \\
\text { METHODOLOGY }\end{array}$ & DATA & $\begin{array}{l}\text { COUNTRY } \\
\text { (TIME PERIOD) }\end{array}$ & Cross EFFECT \\
\hline Foster et al. (1998) & Labour productivity & $\begin{array}{l}\text { Net entry component } \\
\text { Employment weight } \\
\text { Output weight }\end{array}$ & Establishment level & $\begin{array}{l}\text { U.S. } \\
(1979-1989)\end{array}$ & $\begin{array}{l}\text { (-) Employment weight } \\
(+) \text { Output weight }\end{array}$ \\
\hline Bottazzi et al. (2010) & Labour productivity & $\begin{array}{l}\text { No net entry component } \\
\text { Employment weight } \\
\text { Output weight }\end{array}$ & Firm level & $\begin{array}{l}\text { Italy/(1991-2004) } \\
\text { France/(1989-2004) }\end{array}$ & $\begin{array}{l}\text { (-) Employment weight } \\
\text { (-) Output weight }\end{array}$ \\
\hline Baily et al. (1996) & Labour productivity & $\begin{array}{l}\text { No net entry component } \\
\text { Employment weight }\end{array}$ & Establishment level & $\begin{array}{l}\text { U.S. } \\
(1979-1989)\end{array}$ & $\begin{array}{l}\text { (-) for successful downsizers } \\
(+) \text { for successful upsizers }\end{array}$ \\
\hline Bartelsman et al. (2009) & Labour productivity & $\begin{array}{l}\text { Net entry component } \\
\text { Employment weight }\end{array}$ & Micro-aggregated data & $\begin{array}{l}14 \text { countries } \\
\text { Different time spans }\end{array}$ & $\begin{array}{l}\text { Strongly }(-) \text { for low-tech ind. } \\
\text { Mildly (-) for medium/hight-tech }\end{array}$ \\
\hline Bassanini (2010) & $\begin{array}{l}\text { Labour productivity } \\
\text { Multi-factor productivity }\end{array}$ & $\begin{array}{l}\text { Employment weight } \\
\text { (conditioning on firm } \\
\text { characteristics) }\end{array}$ & Firm level & $\begin{array}{l}10 \text { countries } \\
\text { Different time spans }\end{array}$ & $\begin{array}{l}\text { (-) for all firms } \\
\text { (-) or null for shrinking } \\
\text { (+) for growing firms }\end{array}$ \\
\hline Fagerberg (2000) & Labour productivity & $\begin{array}{l}\text { No net entry component } \\
\text { Employment weight }\end{array}$ & UNIDO-Sectoral level & $\begin{array}{l}39 \text { countries } \\
(1977-1990)\end{array}$ & $(-)$ for most countries \\
\hline
\end{tabular}

Table 5: Synoptic table: industry-level studies

\begin{tabular}{|c|c|c|c|c|c|}
\hline $\begin{array}{l}\text { SECTORAL LEVEL } \\
\text { StUdy }\end{array}$ & $\begin{array}{l}\text { DEPENDENT VARIABLE \& } \\
\text { ANALYSIS }\end{array}$ & METHODOLOGY & DATA & $\begin{array}{l}\text { COUNTRY } \\
\text { (Time PERIOd) }\end{array}$ & Results \\
\hline $\begin{array}{l}\text { Mastrostefano } \\
\text { and Pianta (2009) }\end{array}$ & $\begin{array}{l}\text { Employment growth \& } \\
\text { Demand, wages, } \\
\text { diffusion of technology, } \\
\text { product innovation }\end{array}$ & $\begin{array}{l}\text { GLS fixed effects } \\
\text { OLS }\end{array}$ & $\begin{array}{l}\text { CIS 2-3 } \\
\text { OECD STAN } \\
\text { (manufacturing) }\end{array}$ & $\begin{array}{l}10 \text { European countries } \\
(1994-2001)\end{array}$ & $\begin{array}{l}(+) \text { Effect of demand growth, } \\
(-) \text { role of wage changes, } \\
\text { low effects of } \\
\text { diffusion of innovation, } \\
\text { (+) role of product innovation, } \\
\text { only in high-innovation industries }\end{array}$ \\
\hline $\begin{array}{l}\text { Buerger et al. } \\
(2012)\end{array}$ & $\begin{array}{l}\text { Employment growth \& } \\
\text { R\&D and patents }\end{array}$ & VAR & $\begin{array}{l}\text { Regional data } \\
\text { other sources } \\
\text { (manufacturing) }\end{array}$ & $\begin{array}{l}\text { Germany } \\
(1999-2005)\end{array}$ & $\begin{array}{l}\text { Sector specific patterns } \\
(+) \text { effects in electrics/electronics } \\
\text { and medical instruments }\end{array}$ \\
\hline Merikull (2010) & $\begin{array}{l}\text { Job flows - } \\
\text { employment growth \& } \\
\text { Product and process } \\
\text { innovation }\end{array}$ & $\begin{array}{l}\text { OLS, FE, } \\
\text { GMM }\end{array}$ & $\begin{array}{l}\text { CIS } 3-4 \\
\text { Business Register }\end{array}$ & $\begin{array}{l}\text { Estonia } \\
(1994-2006)\end{array}$ & $\begin{array}{l}\text { Product innovation has } \\
\text { mild effects at firm-level, } \\
(+) \text { at industry. } \\
\text { Process innovation weakly }(+) \\
\text { at firm-level, (-) at industry. } \\
\text { Limited net effects }\end{array}$ \\
\hline $\begin{array}{l}\text { Evangelista and } \\
\text { Savona (2003) }\end{array}$ & $\begin{array}{l}\text { Employment (qualitative } \\
\text { var.) \& different innovation } \\
\text { variables }\end{array}$ & Binary logit & CIS 2 & $\begin{array}{l}\text { Italy } \\
(1993-1995)\end{array}$ & $\begin{array}{l}\text { At firm-level, new services } \\
\text { have a }(+) \text { impact on employment. } \\
\text { At sectoral level, the }(+) \text { impact } \\
\text { is only in science and } \\
\text { technology based sectors and } \\
(-) \text { in ICT and technology } \\
\text { using industries }\end{array}$ \\
\hline
\end{tabular}

